\title{
Characterization of coarse particulate matter in the western United States: a comparison between observation and modeling
}

\author{
R. Li ${ }^{1,2}$, C. Wiedinmyer ${ }^{1}$, K. R. Baker ${ }^{3}$, and M. P. Hannigan ${ }^{2}$ \\ ${ }^{1}$ National Center for Atmospheric Research, 1850 Table Mesa Drive, Boulder, CO, USA \\ ${ }^{2}$ Department of Mechanical Engineering, University of Colorado, Boulder, CO, USA \\ ${ }^{3}$ Office of Air Quality, Planning, and Standards (OAQPS), United States Environmental Protection Agency, \\ Research Triangle Park, NC, USA \\ Correspondence to: R. Li (rlimail@yahoo.ca)
}

Received: 13 January 2012 - Published in Atmos. Chem. Phys. Discuss.: 3 May 2012

Revised: 2 October 2012 - Accepted: 16 January 2013 - Published: 1 February 2013

\begin{abstract}
We provide a regional characterization of coarse particulate matter $\left(\mathrm{PM}_{10-2.5}\right)$ spanning the western United States based on the analysis of measurements from 50 sites reported in the US EPA Air Quality System (AQS) and two state agencies. We found that the observed $\mathrm{PM}_{10-2.5}$ concentrations show significant spatial variability and distinct spatial patterns, associated with the distributions of land use/land cover and soil moisture. The highest concentrations were observed in the southwestern US, where sparse vegetation, shrublands or barren lands dominate with lower soil moistures, whereas the lowest concentrations were observed in areas dominated by grasslands, forest, or croplands with higher surface soil moistures. The observed $\mathrm{PM}_{10-2.5}$ concentrations also show variable seasonal, weekly, and diurnal patterns, indicating a variety of sources and their relative importance at different locations. The observed results were compared to modeled $\mathrm{PM}_{10-2.5}$ concentrations from an annual simulation using the Community Multiscale Air Quality modeling system (CMAQ) that has been designed for regulatory or policy assessments of a variety of pollutants including $\mathrm{PM}_{10}$, which consists of $\mathrm{PM}_{10-2.5}$ and fine particulate matter $\left(\mathrm{PM}_{2.5}\right)$. The model under-predicts $\mathrm{PM}_{10-2.5}$ observations at 49 of 50 sites, among which 14 sites have annual observation means that are at least five times greater than model means. Model results also fail to reproduce their spatial patterns. Important sources (e.g. pollen, bacteria, fungal spores, and geogenic dust) were not included in the emission inventory used and/or the applied emissions were greatly under-estimated. Unlike the observed patterns that are more complex, modeled $\mathrm{PM}_{10-2.5}$ concentrations show the simi-
\end{abstract}

lar seasonal, weekly, and diurnal pattern; the temporal allocations in the modeling system need improvement. CMAQ does not include organic materials in $\mathrm{PM}_{10-2.5}$; however, speciation measurements show that organics constitute a significant component. The results improve our understanding of sources and behavior of $\mathrm{PM}_{10-2.5}$ and suggest avenues for future improvements to models that simulate $\mathrm{PM}_{10-2.5}$ emissions, transport and fate.

\section{Introduction}

Concentrations of atmospheric particulate matter (PM) are currently regulated by the US Environmental Protection Agency (EPA) with National Ambient Air Quality Standards (NAAQS) for both $\mathrm{PM}_{2.5}$ (fine particles; particulate matter with a diameter less than $2.5 \mu \mathrm{m}$ ) and $\mathrm{PM}_{10}$ (particulate matter with a diameter less than $10 \mu \mathrm{m}$ ) (http://www. epa.gov/air/criteria.html). In the United States, there is an annual average standard and a 24-h average standard for $\mathrm{PM}_{2.5}$. The 3-yr average of the annual mean $\mathrm{PM}_{2.5}$ concentrations must not exceed $15.0 \mathrm{\mu g} \mathrm{m}^{-3}$, and the 3 -yr average of the 98th percentile of 24-h concentrations at each population-oriented monitor within an area must not exceed $35 \mu \mathrm{g} \mathrm{m}^{-3}$. The 24-h average $\mathrm{PM}_{10}$ concentration standard of $150 \mu \mathrm{g} \mathrm{m}^{-3}$ must not be exceeded more than once per year on average over 3 yr. The European Community also regulates atmospheric particulate matter with legal limit values (e.g. daily limit value of $50 \mathrm{\mu g} \mathrm{m}^{-3}$ for $\mathrm{PM}_{10}$ ) under Directive 2008/50/EC of the European Parliament and of the Council 
of 21 May 2008 on ambient air quality and cleaner air for Europe (http://ec.europa.eu/environment/air/quality/legislation/ existing_leg.htm).

Airborne $\mathrm{PM}_{10}$ consists of both fine particles $\left(\mathrm{PM}_{2.5}\right)$ and coarse particles $\left(\mathrm{PM}_{10-2.5}\right.$; particulate matter with a diameter between 2.5 and $10 \mu \mathrm{m}$ ). Therefore, to meet the $\mathrm{PM}_{10}$ standards, not only $\mathrm{PM}_{2.5}$ but $\mathrm{PM}_{10-2.5}$ concentrations need to be controlled. Moreover, recent epidemiological and toxicological studies show that $\mathrm{PM}_{10-2.5}$ concentrations have been linked to mortality (e.g. Malig and Ostro, 2009; Perez et al., 2008; Zanobetti and Schwartz, 2009) as well as respiratory and cardiovascular morbidity (Branis et al., 2010; Brunekreef and Forsberg, 2005; Host et al., 2008; Sandstrom and Forsberg, 2008; Zhang et al., 2002).

In addition to health impacts and legal regulations, atmospheric particles can considerably affect climate directly by influencing incoming and outgoing radiation, and indirectly by serving as cloud condensation nuclei $(\mathrm{CCN})$ and ice nuclei (IN), influencing the formation and lifetimes of clouds and precipitation as well as atmospheric chemistry (DeMott et al., 2003; Koehler et al., 2009; Krueger et al., 2004; Kumar et al., 2009, 2011; Solomon et al., 2007; Wang et al., 2007; Wurzler et al., 2000). Aerosols can also affect biogeochemical cycles, which can alter carbon fluxes and further interact with climate, by influencing physical environment (e.g. diffuse radiation, precipitation and temperature) and by depositing nutrients (e.g. nitrogen, phosphorous, and iron) or toxins (e.g. copper) to ecosystems (Mahowald, 2011; Paytan et al., 2009). The indirect effects of aerosols on climate are very uncertain (Mahowald, 2011; Solomon et al., 2007). $\mathrm{PM}_{10-2.5}$ components (e.g. sea salt and soil dust) contribute considerably to global aerosol mass, optical thickness, and surface particle concentrations (Birmili et al., 2008; Textor et al., 2006). Therefore, to better quantify the effects of atmospheric particles, the characteristics of not only fine particles but coarse particles need to be understood.

While $\mathrm{PM}_{2.5}$ is primarily emitted from combustion processes or formed in the atmosphere through chemical reactions and gas-to-particle conversion processes, $\mathrm{PM}_{10-2.5}$ predominantly originates from abrasive mechanical processes, with sources such as geogenic dust, sea salt, dust from construction activities, tire wear, brake wear, and organic bioaerosols such as bacteria, pollen and fungal spores (Edgerton et al., 2009; Harrison et al., 2001; Kelly et al., 2010; Malm et al., 2007; Sesartic and Dallafior, 2011; Zhu et al., 2009). Controlling variables on these sources include land use, land cover, and environmental conditions (e.g. temperature, soil moisture, snow/ice cover, wind speed). Some of these sources are a result of natural processes (e.g. windblown dust in a desert), while others are more closely tied to human activities (e.g. construction). Additionally, $\mathrm{PM}_{10-2.5}$ has a higher deposition velocity, i.e., shorter atmospheric residence time, than $\mathrm{PM}_{2.5}$. These combined facts mean that $\mathrm{PM}_{10-2.5}$ will have different spatial and temporal variability than $\mathrm{PM}_{2.5}$. Recent studies investigated the characteristics of $\mathrm{PM}_{10-2.5}$ in a few US cities including Los Angeles, CA (Pakbin et al., 2010), Detroit, MI (Thornburg et al., 2009), Rochester, NY (Lagudu et al., 2011), and Denver and Greeley, CO (Clements et al., 2012). However, little research has investigated the spatial and temporal variability of $\mathrm{PM}_{10-2.5}$ concentrations at a regional scale, or the relationships between concentrations and land use/land cover and soil moisture dependent on geographical location.

Accurate $\mathrm{PM}_{10-2.5}$ modeling tools are needed by both the scientific community and regulatory agencies for mitigation strategy development and health effect assessments. $\mathrm{PM}_{10-2.5}$ is simulated as part of the US EPA's Community Multiscale Air Quality (CMAQ) modeling system (Byun and Schere, 2006). However, the model performance for $\mathrm{PM}_{10-2.5}$ has not been explicitly assessed because over the past decade both PM model and measurement studies have primarily focused on $\mathrm{PM}_{2.5}$. CMAQ and other chemical transport models have been primarily assessed for their performance for $\mathrm{PM}_{2.5}$ or $\mathrm{PM}_{10}$ (Baldasano et al., 2011; Chuang et al., 2011; Foley et al., 2010; Konovalov et al., 2011; Lonati et al., 2010; Sokhi et al., 2008; Wang et al., 2008). Yet, since fine and coarse particles have different sources as well as different chemical composition and potential health effects, they should be considered as separate classes of pollutants as suggested by Wilson and Suh (1997) and assessed individually.

Given the importance of coarse particles for air quality, climate, and human health risk assessments, improvements to our knowledge of the sources and characteristics of $\mathrm{PM}_{10-2.5}$ are essential. In this paper, we investigate the temporal and spatial patterns of measured $\mathrm{PM}_{10-2.5}$ concentrations in the western United States. The results of this analysis provide insights to the sources and fate of $\mathrm{PM}_{10-2.5}$ and motivate more accurate models that describe $\mathrm{PM}_{10-2.5}$ emissions, transport, and atmospheric concentrations.

\section{Methods}

This study was carried out using both observations and model simulations for an entire year (2005) over a domain that covers the western United States (see Fig. 1).

\subsection{Measurement data}

While abundant ambient $\mathrm{PM}_{2.5}$ and $\mathrm{PM}_{10}$ mass concentration data are available, direct measurements of $\mathrm{PM}_{10-2.5}$ mass concentrations are very limited. Therefore, our study obtained co-located measurements of $\mathrm{PM}_{10}$ and $\mathrm{PM}_{2.5}$. We obtained all available observed hourly-averaged $\mathrm{PM}_{10}$ and $\mathrm{PM}_{2.5}$ concentration data in the western United States (see Figs. 1 and 2) for 2005 from the Air Quality System (AQS) datamart (http://www.epa.gov/ttn/airs/aqsdatamart/) and from two state agencies. From the AQS, we obtained hourly co-located $\mathrm{PM}_{10}$ and $\mathrm{PM}_{2.5}$ concentration data for 


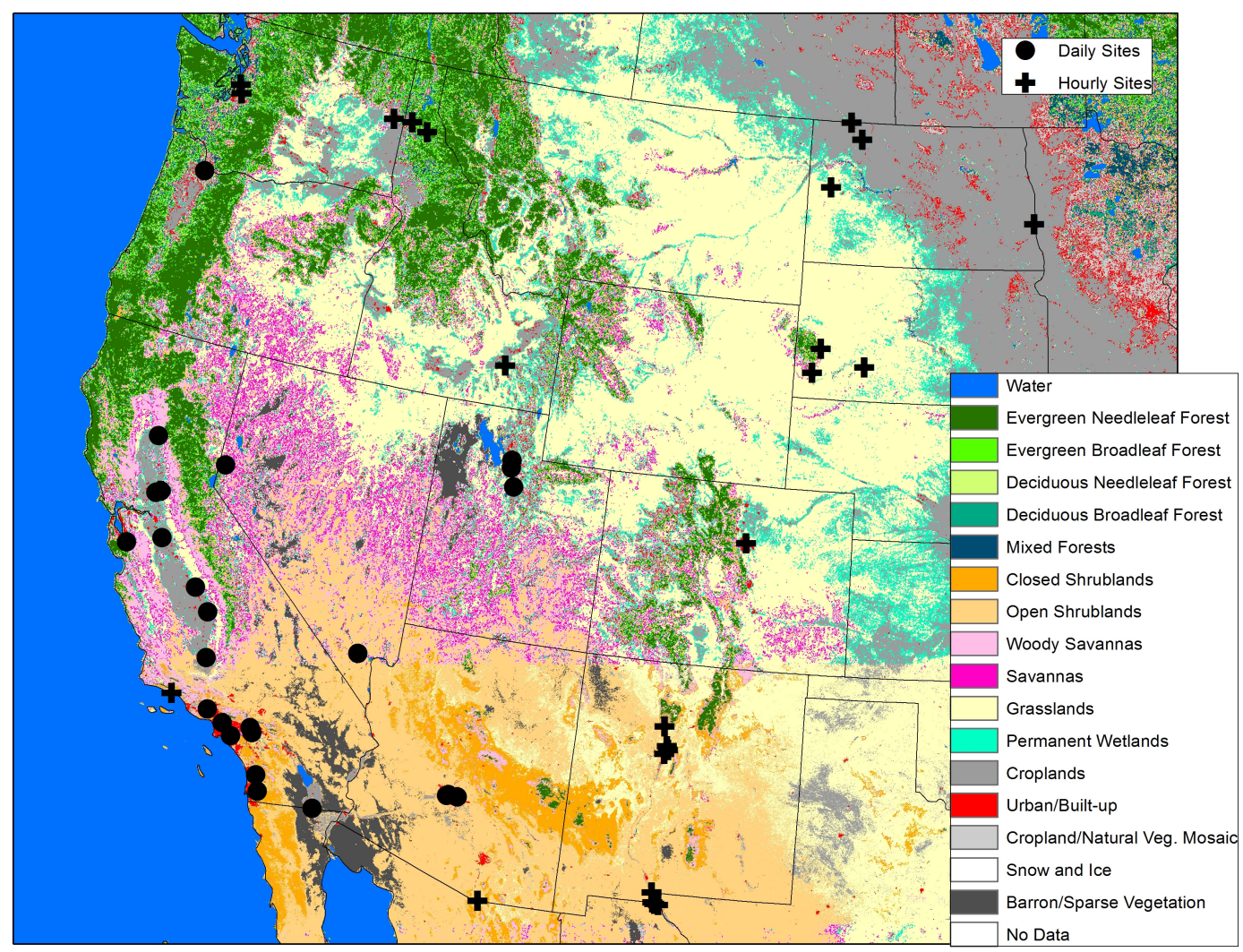

Fig. 1. Map of monitoring locations and land use/land cover in the study domain (sites having hourly data are represented with black plus symbols, and black circles represent sites having daily data).

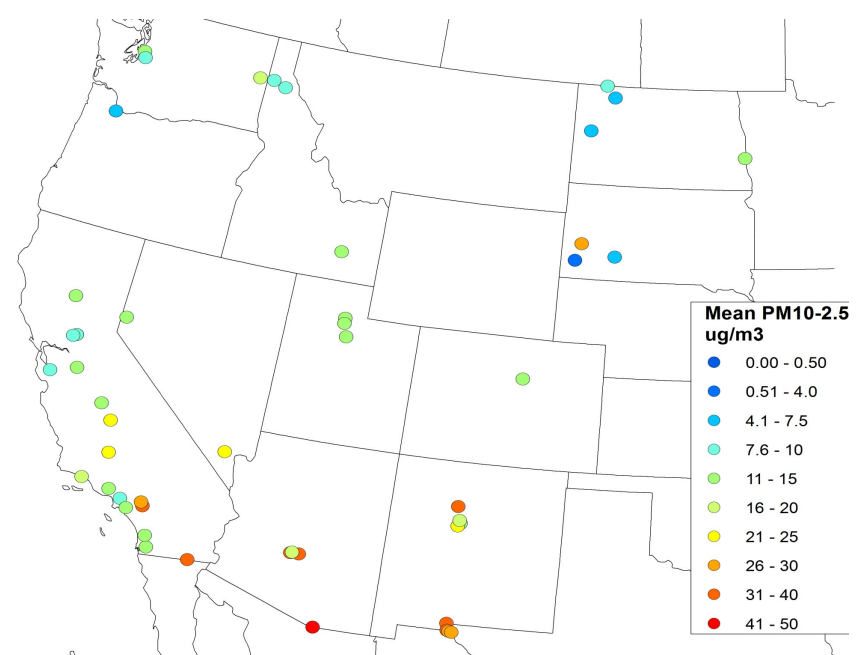

Fig. 2. Measured annual mean $\mathrm{PM}_{10-2.5}$ concentrations at measurement sites in the western United States.

23 sites. Co-located hourly measurements from two additional sites were obtained from state agencies: Santa Barbara, CA (AQS Site Number: 060830011) from the California Air Resources Board (http://www.arb.ca.gov/aqd/ aqdcd/aqdcddld.htm), and Denver, CO (AQS Site Number: 080310002) from Colorado Department of Public Health and Environment (B. L. Rink, personal communication, 2011). These 25 sites are shown as plus symbols in Fig. 1 (also described in Table 1). To fill spatial gaps of hourly data, we obtained daily measurements (24-h filter samples) from the AQS for an additional 25 sites in the domain, shown as circles in Fig. 1 (also described in Table 1). The 24-h measurements were taken every three days at two sites (Riverside site, CA, AQS Site Number of 060830011 and Salt Lake City, Utah, AQS Site Number of 490353006), and every 6 days at the other sites. Details of all measurement sites, including associated environmental conditions output from the Pennsylvania State University/National Center for Atmospheric Research Mesoscale Meteorology Model (MM5) (i.e. hourly average temperature, wind speed, and surface soil moisture), are presented in Table 1 . The concentrations of $\mathrm{PM}_{10-2.5}$ were calculated as the difference between co-located $\mathrm{PM}_{10}$ and $\mathrm{PM}_{2.5}$ concentrations at all hourly and daily sites.

\subsection{Model simulations}

To obtain insights for regional $\mathrm{PM}_{10-2.5}$ modeling, model simulations were carried out for the western United States. The Community Multiscale Air Quality (CMAQ) modeling 
Table 1. Details of measurement sites.

\begin{tabular}{|c|c|c|c|c|c|c|c|c|c|c|c|c|}
\hline \multirow[b]{2}{*}{ Site Name } & \multirow[b]{2}{*}{ AQS Site ID } & \multirow[b]{2}{*}{ Latitude } & \multirow[b]{2}{*}{ Longitude } & \multicolumn{3}{|c|}{$\begin{array}{c}\text { Hourly } \\
\text { Temperature }\left({ }^{\circ} \mathrm{C}\right)\end{array}$} & \multicolumn{3}{|c|}{$\begin{array}{l}\text { Hourly Wind Speed } \\
\qquad\left(\mathrm{m} \mathrm{s}^{-1}\right)\end{array}$} & \multicolumn{3}{|c|}{$\begin{array}{l}\text { Hourly Soil Moisture } \\
(\text { top } 1 \mathrm{~cm})\left(\mathrm{m}^{3} \mathrm{~m}^{-3}\right)\end{array}$} \\
\hline & & & & Mean & 5 th & 95 th & Mean & 5 th & 95th & Mean & 5 th & 95th \\
\hline Mexicali, CA & 60250005 & 32.676 & -115.483 & 23.1 & 8.9 & 41.2 & 2.87 & 0.57 & 6.96 & 0.07 & 0.03 & 0.15 \\
\hline NW Phoenix, AZ & 40130019 & 33.484 & -112.143 & 22.1 & 7.8 & 38.7 & 1.97 & 0.31 & 4.27 & 0.08 & 0.02 & 0.35 \\
\hline N Phoenix, AZ & 40139997 & 33.504 & -112.096 & 22.1 & 7.8 & 38.7 & 1.97 & 0.31 & 4.27 & 0.08 & 0.02 & 0.35 \\
\hline E Scottsdale, AZ & 40137020 & 33.488 & -111.856 & 21.5 & 8.3 & 36.7 & 2.81 & 0.66 & 5.90 & 0.11 & 0.04 & 0.40 \\
\hline Bakersfield, CA & 60290014 & 35.356 & -119.040 & 19.4 & 8.3 & 36.0 & 2.07 & 0.38 & 4.63 & 0.08 & 0.02 & 0.29 \\
\hline Las Vegas, NV & 320030561 & 36.164 & -115.114 & 18.8 & 5.3 & 35.3 & 3.22 & 0.49 & 7.28 & 0.10 & 0.03 & 0.26 \\
\hline Visalia, CA & 61072002 & 36.332 & -119.290 & 18.5 & 7.3 & 36.7 & 2.19 & 0.57 & 4.60 & 0.09 & 0.02 & 0.36 \\
\hline Fresno, CA & 60190008 & 36.781 & -119.772 & 18.4 & 6.9 & 36.5 & 2.29 & 0.40 & 4.76 & 0.09 & 0.01 & 0.34 \\
\hline Riverside, CA & 60658001 & 34.000 & -117.416 & 18.1 & 8.7 & 31.5 & 2.86 & 0.49 & 7.23 & 0.12 & 0.03 & 0.27 \\
\hline El Paso East, TX & 481410055 & 31.747 & -106.403 & 18.1 & 4.4 & 32.8 & 3.40 & 0.85 & 7.32 & 0.09 & 0.03 & 0.30 \\
\hline N Chico, CA & 60070002 & 39.758 & -121.842 & 17.8 & 6.3 & 36.1 & 2.97 & 0.59 & 6.64 & 0.13 & 0.02 & 0.43 \\
\hline El Paso North (Anthony), NM & 350130016 & 32.004 & -106.599 & 17.8 & 4.9 & 31.5 & 3.14 & 0.75 & 6.96 & 0.11 & 0.03 & 0.24 \\
\hline El Paso1, TX & 481410037 & 31.768 & -106.501 & 17.7 & 4.4 & 31.7 & 3.44 & 0.87 & 7.27 & 0.10 & 0.03 & 0.30 \\
\hline El Paso West, NM & 350130017 & 31.796 & -106.558 & 17.7 & 4.4 & 31.7 & 3.44 & 0.87 & 7.27 & 0.10 & 0.03 & 0.30 \\
\hline Los Angeles, CA & 60371103 & 34.067 & -118.227 & 17.7 & 9.8 & 30.7 & 1.69 & 0.24 & 3.71 & 0.11 & 0.02 & 0.32 \\
\hline East San Diego, CA & 60730003 & 32.791 & -116.942 & 17.6 & 9.8 & 29.7 & 2.15 & 0.33 & 4.63 & 0.11 & 0.04 & 0.36 \\
\hline Anaheim, CA & 60590007 & 33.831 & -117.938 & 17.4 & 9.8 & 29.9 & 1.66 & 0.25 & 3.72 & 0.12 & 0.02 & 0.27 \\
\hline Nogales, AZ & 40230004 & 31.337 & -110.937 & 17.1 & 3.6 & 32.1 & 3.43 & 0.97 & 7.07 & 0.08 & 0.03 & 0.34 \\
\hline North San Diego, CA & 60731002 & 33.128 & -117.075 & 17.1 & 9.3 & 29.4 & 2.22 & 0.31 & 5.22 & 0.09 & 0.02 & 0.32 \\
\hline North Riverside, CA & 60712002 & 34.100 & -117.492 & 17.0 & 7.9 & 29.4 & 3.44 & 0.44 & 9.98 & 0.12 & 0.03 & 0.27 \\
\hline Modesto, CA & 60990005 & 37.642 & -120.994 & 16.9 & 6.0 & 34.0 & 3.13 & 0.69 & 6.63 & 0.10 & 0.02 & 0.29 \\
\hline East Sacramento, CA & 60670006 & 38.614 & -121.367 & 16.5 & 5.2 & 34.6 & 2.27 & 0.48 & 4.66 & 0.12 & 0.02 & 0.44 \\
\hline East Sacramento, CA & 60670006 & 38.614 & -121.367 & 16.5 & 5.2 & 34.6 & 2.28 & 0.48 & 4.67 & 0.12 & 0.02 & 0.44 \\
\hline Santa Barbara, CA & 60830011 & 34.428 & -119.690 & 16.4 & 8.1 & 27.8 & 2.62 & 0.37 & 5.64 & 0.11 & 0.04 & 0.36 \\
\hline South Sacramento, CA & 60670010 & 38.558 & -121.492 & 16.4 & 4.9 & 34.2 & 2.55 & 0.51 & 5.27 & 0.11 & 0.02 & 0.43 \\
\hline East Simi Valley, CA & 61112002 & 34.278 & -118.685 & 16.3 & 7.7 & 29.9 & 4.18 & 0.70 & 11.33 & 0.13 & 0.04 & 0.41 \\
\hline San Jose, CA & 60850005 & 37.349 & -121.895 & 15.0 & 5.7 & 29.6 & 2.21 & 0.41 & 4.58 & 0.13 & 0.04 & 0.41 \\
\hline Albuquerque South, NM & 350010029 & 35.017 & -106.657 & 14.1 & 0.3 & 29.9 & 2.86 & 0.52 & 6.66 & 0.15 & 0.03 & 0.26 \\
\hline Albuquerque East, NM & 350010019 & 35.107 & -106.564 & 13.9 & -0.2 & 30.1 & 2.52 & 0.57 & 5.41 & 0.09 & 0.02 & 0.25 \\
\hline Albuquerque North, NM & 350011013 & 35.193 & -106.614 & 13.2 & -1.1 & 29.6 & 2.72 & 0.61 & 6.31 & 0.13 & 0.04 & 0.38 \\
\hline Denver, CO & 80310002 & 39.751 & -104.988 & 11.4 & -5.5 & 30.6 & 2.73 & 0.63 & 6.07 & 0.18 & 0.07 & 0.46 \\
\hline N Portland, OR & 410510246 & 45.561 & -122.679 & 11.3 & 1.1 & 23.9 & 2.79 & 0.57 & 5.94 & 0.24 & 0.05 & 0.47 \\
\hline Sandoval, NM & 350439004 & 35.615 & -106.724 & 11.3 & -3.0 & 27.8 & 3.99 & 1.09 & 8.31 & 0.18 & 0.05 & 0.42 \\
\hline South Seattle, WA & 530332004 & 47.386 & -122.232 & 10.9 & 0.7 & 22.9 & 2.22 & 0.51 & 4.47 & 0.21 & 0.04 & 0.38 \\
\hline Seattle, WA & 530330057 & 47.563 & -122.341 & 10.9 & 0.2 & 22.9 & 2.21 & 0.44 & 4.53 & 0.20 & 0.05 & 0.45 \\
\hline S Salt Lake City, UT & 490494001 & 40.341 & -111.714 & 10.8 & -0.6 & 22.6 & 4.18 & 1.12 & 7.72 & 1.00 & 1.00 & 1.00 \\
\hline Badlands, SD & 460710001 & 43.746 & -101.941 & 10.5 & -12.5 & 29.8 & 4.15 & 1.22 & 8.41 & 0.16 & 0.06 & 0.46 \\
\hline N Salt Lake City, UT & 490110004 & 40.903 & -111.884 & 9.9 & -5.3 & 28.5 & 3.19 & 0.82 & 5.57 & 0.21 & 0.04 & 0.49 \\
\hline Rapid City, SD & 461030020 & 44.087 & -103.274 & 9.8 & -11.8 & 28.4 & 4.44 & 1.15 & 9.80 & 0.16 & 0.06 & 0.45 \\
\hline Salt Lake City, UT & 490353006 & 40.736 & -111.872 & 9.7 & -6.4 & 28.6 & 3.00 & 0.77 & 5.49 & 0.20 & 0.04 & 0.45 \\
\hline Spokane, WA & 530630016 & 47.661 & -117.358 & 9.2 & -8.2 & 27.0 & 2.55 & 0.50 & 5.50 & 0.17 & 0.04 & 0.49 \\
\hline Wind Cave National Park, SD & 460330132 & 43.558 & -103.484 & 9.1 & -9.3 & 26.8 & 3.60 & 0.75 & 7.41 & 0.16 & 0.05 & 0.45 \\
\hline Reno, NV & 320310016 & 39.525 & -119.808 & 9.0 & -3.3 & 26.7 & 3.10 & 0.79 & 6.47 & 0.15 & 0.02 & 0.44 \\
\hline Coeur D’Alene, ID & 160550006 & 47.682 & -116.766 & 8.3 & -8.1 & 25.2 & 2.84 & 0.80 & 5.82 & 0.26 & 0.06 & 0.49 \\
\hline NW Pocatello, ID & 160770011 & 42.913 & -112.536 & 7.6 & -9.9 & 26.7 & 3.36 & 0.80 & 6.49 & 0.23 & 0.03 & 0.45 \\
\hline Pinehurst, ID & 160790017 & 47.536 & -116.237 & 6.9 & -9.5 & 23.4 & 2.82 & 0.84 & 5.40 & 0.29 & 0.08 & 0.49 \\
\hline Overlook, ND & 380530002 & 47.581 & -103.300 & 6.6 & -18.0 & 25.7 & 4.44 & 1.59 & 8.39 & 0.21 & 0.06 & 0.45 \\
\hline Fargo, ND & 380171004 & 46.934 & -96.855 & 5.7 & -22.7 & 26.8 & 4.17 & 1.23 & 8.47 & 0.26 & 0.06 & 0.48 \\
\hline Crop\&River, ND & 380130002 & 48.990 & -102.782 & 4.8 & -19.1 & 24.5 & 4.37 & 1.53 & 8.14 & 0.24 & 0.05 & 0.48 \\
\hline Thompson Lake, ND & 380130004 & 48.642 & -102.402 & 4.7 & -19.3 & 23.6 & 4.90 & 1.75 & 8.87 & 0.25 & 0.06 & 0.45 \\
\hline
\end{tabular}

system v4.7.1 (Byun and Schere, 2006; Foley et al., 2010) was used to simulate the transport and chemistry of atmospheric gases and particles. The model configuration included the AERO5 aerosol module having secondary organic aerosol treatment for fine particles (Carlton et al., 2010), ISORROPIA inorganic chemistry (Nenes et al., 1999), the
Carbon-Bond 05 (CB05) gas phase chemistry mechanism (Sarwar et al., 2008; Whitten et al., 2010), aqueous phase chemistry for sulfur and organic oxidation (Carlton et al., 2008), and sea salt treatment (Kelly et al., 2010). The CMAQ aerosol module represents PM in three lognormal modes: the Aitken ("I" mode) with diameters up to about $0.1 \mu \mathrm{m}$, the 
Table 2. Summary of statistical analyses of measured and modeled $\mathrm{PM}_{10-2.5}$ concentrations.

\begin{tabular}{|c|c|c|c|c|c|c|c|c|c|c|c|c|}
\hline \multirow[t]{2}{*}{ Site Name } & \multirow[t]{2}{*}{$\begin{array}{r}\text { Number of } \\
\text { Samples }\end{array}$} & \multicolumn{4}{|c|}{$\begin{array}{c}\text { Measured } \mathrm{PM}_{10-2.5} \\
\left(\mu \mathrm{g} \mathrm{m}^{-3}\right)\end{array}$} & \multicolumn{4}{|c|}{$\begin{array}{l}\text { Modeled } \mathrm{PM}_{10-2.5} \\
\qquad\left(\mu \mathrm{g} \mathrm{m}^{-3}\right)\end{array}$} & \multicolumn{3}{|c|}{$\begin{array}{c}\text { Ratio of Measured to } \\
\text { Modeled } \mathrm{PM}_{10-2.5}\end{array}$} \\
\hline & & Mean & 5 th & 95 th & $\mathrm{CV}$ & Mean & 5 th & 95 th & $\mathrm{CV}$ & Mean & 95th & $\mathrm{CV}$ \\
\hline South Seattle, WA & 8675 & 9.0 & 0.0 & 25.3 & 1.0 & 1.9 & 0.4 & 4.2 & 0.7 & 4.8 & 6.1 & 1.5 \\
\hline El Paso1, TX & 8664 & 25.2 & 1.3 & 80.6 & 1.5 & 7.8 & 1.3 & 24.0 & 1.0 & 3.2 & 3.4 & 1.6 \\
\hline El Paso North (Anthony), NM & 8642 & 34.8 & 4.4 & 96.2 & 1.5 & 18.4 & 3.0 & 49.0 & 0.8 & 1.9 & 2.0 & 1.8 \\
\hline Seattle, WA & 8622 & 14.8 & 0.3 & 38.0 & 1.0 & 2.2 & 0.5 & 4.7 & 0.6 & 6.8 & 8.0 & 1.6 \\
\hline Fargo, ND & 8606 & 12.1 & 2.6 & 34.6 & 1.0 & 6.1 & 0.9 & 16.8 & 0.9 & 2.0 & 2.1 & 1.2 \\
\hline Thompson Lake, ND & 8605 & 6.7 & 1.7 & 17.7 & 1.0 & 1.8 & 0.3 & 4.9 & 0.9 & 3.6 & 3.6 & 1.1 \\
\hline Crop\&River, ND & 8508 & 8.1 & 1.2 & 22.0 & 1.0 & 3.3 & 0.4 & 8.9 & 0.9 & 2.4 & 2.5 & 1.1 \\
\hline Coeur D'Alene, ID & 8478 & 8.6 & 0.0 & 26.0 & 1.5 & 5.3 & 1.1 & 14.0 & 0.8 & 1.6 & 1.9 & 1.8 \\
\hline Albuquerque East, NM & 8471 & 10.0 & 0.0 & 27.7 & 1.2 & 8.1 & 1.5 & 20.1 & 0.8 & 1.2 & 1.4 & 1.6 \\
\hline El Paso West, NM & 8455 & 34.8 & 2.4 & 118.8 & 1.9 & 7.8 & 1.3 & 24.0 & 1.0 & 4.5 & 5.0 & 2.0 \\
\hline Albuquerque South, NM & 8447 & 21.8 & 0.0 & 68.8 & 1.6 & 11.9 & 1.9 & 30.1 & 0.8 & 1.8 & 2.3 & 2.0 \\
\hline Wind Cave National Park, SD & 8432 & 2.8 & 0.0 & 8.9 & 1.4 & 0.6 & 0.1 & 1.6 & 0.9 & 4.7 & 5.5 & 1.6 \\
\hline Albuquerque North, NM & 8375 & 17.7 & 0.0 & 57.3 & 1.4 & 10.8 & 1.8 & 26.3 & 0.7 & 1.6 & 2.2 & 1.9 \\
\hline Spokane, WA & 8286 & 15.9 & 0.0 & 52.6 & 1.6 & 4.1 & 0.6 & 11.0 & 0.9 & 3.9 & 4.8 & 1.9 \\
\hline Rapid City, SD & 8268 & 28.4 & 0.4 & 109.5 & 1.5 & 4.4 & 0.9 & 12.5 & 0.9 & 6.5 & 8.8 & 1.7 \\
\hline Badlands, SD & 8259 & 4.9 & 0.0 & 14.5 & 1.5 & 0.8 & 0.1 & 2.1 & 0.8 & 6.4 & 7.0 & 1.8 \\
\hline Sandoval, NM & 8099 & 31.4 & 0.0 & 118.4 & 1.5 & 4.7 & 0.8 & 12.7 & 0.8 & 6.7 & 9.3 & 1.8 \\
\hline Denver, CO & 8036 & 12.0 & 0.0 & 33.1 & 1.0 & 6.2 & 1.2 & 16.8 & 0.8 & 1.9 & 2.0 & 1.2 \\
\hline Overlook, ND & 7996 & 6.1 & 1.0 & 15.5 & 0.9 & 1.0 & 0.2 & 2.6 & 0.9 & 6.3 & 5.9 & 1.0 \\
\hline NW Pocatello, ID & 7928 & 14.3 & 0.0 & 51.7 & 2.0 & 3.6 & 0.7 & 11.1 & 1.1 & 4.0 & 4.7 & 1.9 \\
\hline Santa Barbara, CA & 7533 & 17.5 & 2.0 & 37.0 & 0.7 & 4.6 & 0.7 & 12.5 & 0.8 & 3.8 & 3.0 & 0.8 \\
\hline El Paso East, TX & 7390 & 28.4 & 1.8 & 85.0 & 1.8 & 4.9 & 0.7 & 14.8 & 1.0 & 5.8 & 5.7 & 1.9 \\
\hline Pinehurst, ID & 7162 & 8.5 & 0.0 & 26.5 & 1.6 & 1.2 & 0.2 & 3.4 & 0.9 & 6.9 & 7.9 & 1.8 \\
\hline East Sacramento, CA & 6384 & 11.4 & 0.0 & 26.7 & 0.8 & 4.7 & 1.1 & 11.9 & 0.8 & 2.4 & 2.2 & 1.1 \\
\hline Nogales, AZ & 6135 & 49.4 & 3.5 & 181.9 & 1.5 & 1.8 & 0.4 & 3.9 & 0.6 & 27.7 & 47.0 & 2.4 \\
\hline Riverside, CA & 120 & 31.0 & 4.6 & 59.5 & N/A & 8.1 & 2.8 & 13.4 & N/A & 3.8 & 4.4 & N/A \\
\hline Salt Lake City, UT & 111 & 11.1 & 1.4 & 25.4 & N/A & 4.2 & 1.5 & 10.5 & N/A & 2.6 & 2.4 & N/A \\
\hline S Salt Lake City, UT & 61 & 12.7 & 0.0 & 28.6 & N/A & 3.5 & 1.0 & 6.4 & N/A & 3.6 & 4.5 & N/A \\
\hline Los Angeles, CA & 61 & 9.8 & 0.0 & 18.6 & N/A & 7.9 & 2.9 & 12.5 & N/A & 1.2 & 1.5 & N/A \\
\hline Anaheim, CA & 60 & 11.4 & 1.6 & 21.9 & N/A & 9.5 & 4.4 & 15.7 & N/A & 1.2 & 1.4 & N/A \\
\hline East Sacramento, CA & 59 & 8.2 & 0.0 & 21.6 & N/A & 4.7 & 1.9 & 9.1 & N/A & 1.7 & 2.4 & N/A \\
\hline North Riverside, CA & 58 & 25.6 & 4.7 & 51.0 & N/A & 5.0 & 1.1 & 9.3 & N/A & 5.1 & 5.5 & N/A \\
\hline Fresno, CA & 57 & 14.5 & 1.8 & 35.7 & N/A & 2.6 & 0.9 & 5.3 & N/A & 5.6 & 6.7 & N/A \\
\hline San Jose, CA & 57 & 9.2 & 0.0 & 17.2 & N/A & 9.5 & 4.3 & 17.8 & N/A & 1.0 & 1.0 & N/A \\
\hline N Portland, OR & 57 & 6.7 & 0.0 & 13.4 & N/A & 4.8 & 1.8 & 11.0 & N/A & 1.4 & 1.2 & N/A \\
\hline Reno, NV & 56 & 14.5 & 3.6 & 26.3 & N/A & 5.1 & 1.7 & 10.3 & N/A & 2.8 & 2.6 & N/A \\
\hline NW Phoenix, AZ & 55 & 30.4 & 5.8 & 60.6 & N/A & 10.0 & 4.9 & 16.3 & N/A & 3.0 & 3.7 & N/A \\
\hline N Phoenix, AZ & 55 & 19.4 & 1.9 & 38.8 & N/A & 10.0 & 4.9 & 16.3 & N/A & 1.9 & 2.4 & N/A \\
\hline Las Vegas, NV & 53 & 20.8 & 2.1 & 37.5 & N/A & 12.1 & 5.0 & 25.2 & N/A & 1.7 & 1.5 & N/A \\
\hline East San Diego, CA & 53 & 14.7 & 5.8 & 24.0 & N/A & 7.9 & 2.1 & 13.3 & N/A & 1.9 & 1.8 & N/A \\
\hline N Salt Lake City, UT & 50 & 12.8 & 0.5 & 33.0 & N/A & 5.2 & 1.9 & 12.5 & N/A & 2.4 & 2.6 & N/A \\
\hline Mexicali, CA & 49 & 34.7 & 13.0 & 66.8 & N/A & 6.0 & 2.7 & 10.4 & N/A & 5.8 & 6.4 & N/A \\
\hline Modesto, CA & 49 & 13.1 & 0.3 & 33.9 & N/A & 4.4 & 1.7 & 8.2 & N/A & 3.0 & 4.1 & N/A \\
\hline East Simi Valley, CA & 48 & 11.7 & 1.8 & 24.1 & N/A & 2.6 & 0.7 & 5.4 & N/A & 4.5 & 4.5 & N/A \\
\hline N Chico, CA & 47 & 11.3 & 1.4 & 24.1 & N/A & 1.7 & 0.7 & 3.2 & N/A & 6.6 & 7.6 & N/A \\
\hline South Sacramento, CA & 47 & 8.8 & 0.0 & 23.0 & N/A & 5.2 & 1.8 & 12.4 & N/A & 1.7 & 1.9 & N/A \\
\hline E Scottsdale, AZ & 46 & 39.9 & 9.6 & 74.0 & N/A & 8.7 & 3.9 & 14.6 & N/A & 4.6 & 5.1 & N/A \\
\hline Bakersfield, CA & 46 & 23.4 & 3.7 & 49.9 & N/A & 3.9 & 2.2 & 6.3 & N/A & 6.0 & 7.9 & N/A \\
\hline North San Diego, CA & 45 & 11.2 & 2.1 & 20.7 & N/A & 6.6 & 1.1 & 10.9 & N/A & 1.7 & 1.9 & N/A \\
\hline Visalia, CA & 43 & 21.0 & 1.4 & 49.0 & N/A & 2.4 & 1.1 & 4.4 & N/A & 8.8 & 11.1 & N/A \\
\hline
\end{tabular}


accumulation ("J" mode) with diameters between 0.1 and $2.5 \mu \mathrm{m}$, and coarse particles (" $\mathrm{K}$ " mode) having diameters between 2.5 and $10 \mu \mathrm{m}$. Model estimates of speciated PM in the coarse mode are summed for comparison to the observation data. CMAQ was run for a domain that covers the western United States with a resolution of $12 \mathrm{~km}$ (Figs. 1 and 6). A larger domain with $36 \mathrm{~km}$ square grid cells covering the continental United States, southern Canada, and northern Mexico was used to supply hourly boundary conditions to the $12 \mathrm{~km}$ square grid cell domain. Horizontally and vertically varying initial conditions for the $36 \mathrm{~km}$ domain were extracted from a 2005 global simulation of the GEOS-CHEM model, which also provided spatially varying boundary conditions to the $36 \mathrm{~km}$ CMAQ model simulation on a 3-hourly basis.

Gridded meteorological data for CMAQ and SMOKE (the Sparse Matrix Operator Kernel Emissions modeling system) (Houyoux et al., 2000) were generated using MM5 version 3.7.4 (http://www.mmm.ucar.edu/mm5) with the Pleim-Xiu boundary layer and land surface model (Pleim and Xiu, 2003; Xiu and Pleim, 2001), Kain-Fritsh 2 cumulus parameterization (Kain, 2004), RRTM longwave (Mlawer et al., 1997), Dudhia shortwave (Dudhia, 1989), and Reisner 2 mixed phase moisture schemes (Reisner et al., 1998). Three dimensional analysis nudging was applied only above the boundary layer for moisture and temperature and over the entire vertical atmosphere for winds. The MM5 simulations resolve the vertical atmosphere up to $100 \mathrm{mb}$ with 34 layers, which were reduced to 14 layers by MCIP (Meteorology-Chemistry Interface Processor) (Otte and Pleim, 2010) for emissions and photochemical models with the thinnest layers near the surface to best resolve the diurnal boundary layer cycles. The height of the first model layer is approximately $38 \mathrm{~m}$.

Simulations were performed for the year 2005 with 3 days of spin-up at the end of 2004 that were not included in the analysis. Anthropogenic emissions used to drive the modeling system were based on the 2005 National Emission Inventory (NEI) (http://www.epa.gov/ttnchie1/net/2005inventory. html). Biogenic emissions were estimated with the BEIS model using hourly temperature and solar radiation as input (Pierce et al., 1998). Emissions were processed to hourly gridded input to CMAQ with the SMOKE model version 2.5 (Houyoux et al., 2000). Over the modeling domain, annual $\mathrm{PM}_{10-2.5}$ emissions were dominated by the non-point area sector $(86 \%)$, and their primary sources include fugitive dust from paved roads, unpaved roads, road construction, residential construction, non-residential construction, and agricultural tilling. The inventory did not include emission estimates of wind-blown (geogenic) dust. Sea salt emissions were simulated online within CMAQ following Kelly et al. (2010).

\section{Measurement analyses}

\subsection{Spatial variability}

Table 2 presents a summary of statistical analyses of measured and modeled $\mathrm{PM}_{10-2.5}$ concentration data at all sites having either hourly or daily data, including mean, 5 th percentile, 95th percentile and coefficient of variation $(\mathrm{CV})$. CV is defined as the following:

$\mathrm{CV}=\frac{\text { Standard deviation of time series }}{\text { Mean of time series }}$

The measured $\mathrm{PM}_{10-2.5}$ concentrations have a distinct spatial pattern in the western United States as seen in Fig. 2, which shows observed annual mean $\mathrm{PM}_{10-2.5}$ concentrations at all measurement sites. The highest concentrations were observed at sites in the southwestern US, where shrublands and barren/sparse vegetation dominate (Fig. 1) with generally lower surface soil moistures and higher temperatures (Table 1). The lowest concentrations were found at sites dominated by grasslands, forest, or croplands with generally higher surface soil moistures and lower temperatures (Fig. 1; Table 1). Given the dominance of shrublands and barren/sparse vegetation along with very dry soils in the southwestern US, the higher concentrations in this region are likely caused by fugitive dust emissions, which include geogenic dust. Table 2 shows that all sites having annual mean concentrations that are higher than $17.7 \mu \mathrm{g} \mathrm{m}^{-3}$ are located to the south of $\sim 36^{\circ} \mathrm{N}$, except for the Rapid City site, which has high winds (Table 1) and is significantly influenced by fugitive dust from several industrial facilities (primarily limestone quarrying and processing and cement manufacturing and processing facilities) (http://denr.sd.gov/ documents/neap.pdf).

Measured $\mathrm{PM}_{10-2.5}$ concentrations show strong spatial variations across the western US; the annual mean of measured $\mathrm{PM}_{10-2.5}$ concentrations is more than 17 times higher at the Nogales site in Arizona than at the Wind Cave National Park site in South Dakota. Even sites in close proximity showed significant variability. For example, although the N. Phoenix (040139997) and the N. W. Phoenix (040130019) sites are located very close to each other $(\sim 5 \mathrm{~km})$, the annual mean of measured concentrations differed substantially, from 19.4 to $30.4 \mu \mathrm{g} \mathrm{m}^{-3}$, respectively. In Albuquerque, NM, the annual mean measured concentration is more than two times higher at the Albuquerque South site $\left(21.8 \mu \mathrm{g} \mathrm{m}^{-3}\right)$ than at the Albuquerque East site $\left(10.0 \mu \mathrm{g} \mathrm{m}^{-3}\right)$, although they are located within the same city $\left(\sim 13 \mathrm{~km}\right.$ apart). The differences in $\mathrm{PM}_{10-2.5}$ concentrations between the sites can be even greater at finer temporal resolutions. The daily average concentration on 8 April 2005 (during a $\mathrm{PM}_{10-2.5}$ episode) was 3.75 times higher at the Albuquerque South site $\left(130 \mu \mathrm{g} \mathrm{m}^{-3}\right)$ than at the Albuquerque East site $\left(34.7 \mu \mathrm{g} \mathrm{m}^{-3}\right)$; the maximum hourly concentration on this day was about 6 times higher at the former 
site $\left(571 \mu \mathrm{g} \mathrm{m}^{-3}\right)$ than at the latter site $\left(95.4 \mu \mathrm{g} \mathrm{m}^{-3}\right) . \mathrm{Ob}$ served annual average $\mathrm{PM}_{10-2.5}$ concentrations at the Rapid City site $\left(28.4 \mu \mathrm{g} \mathrm{m}^{-3}\right)$ were more than 10 times higher than those at the Wind Cave National Park site $\left(2.8 \mu \mathrm{g} \mathrm{m}^{-3}\right)$, even though these two sites are only $61 \mathrm{~km}$ apart.

The spatial variability of measured $\mathrm{PM}_{10-2.5}$ at both urban and regional scales was assessed with the correlation coefficients for measured hourly concentrations, calculated between all sites having hourly measurements. Moderate to strong correlations were observed between some sites located in close proximity to one another, including the four sites in El Paso, TX $\left(r^{2}=0.24-0.58\right)$, two sites in Albuquerque, $\mathrm{NM}\left(r^{2}=0.28\right)$, three sites in the northeastern part of the domain (Crop\&River, Thompson Lake, and Overlook in North Dakota; $r^{2}=0.21-0.36$ ), three sites in the northwest (Spokane, Pinehurst, and Coeur D'Alene; $r^{2}=0.23-$ $0.37)$ and two sites in Seattle $\left(r^{2}=0.2\right)$. The p-values for these correlations are all less than 0.0001 , so they were considered significant. No correlation was observed between any other combinations of the site pairs. Very little correlation was seen even over relatively small distances between some sites, such as two sites in New Mexico (Sandoval and Albuquerque East; $r^{2}=0.05$ ) and three sites in South Dakota (Rapid City, Badlands, and Wind Cave National Park; $r^{2}=$ $0.00-0.03$ ), suggesting that these sites are impacted by different sources or have a different proximity to sources. These poor correlations along with high spatial variability also suggest that $\mathrm{PM}_{10-2.5}$ concentrations are often influenced by local factors.

\subsection{Temporal patterns}

\subsubsection{Variability}

Figure 3 presents the time series of measured daily average $\mathrm{PM}_{10-2.5}$ concentrations (red lines or squares) at selected representative sites having hourly (Fig. 3a-c) or 24-h (Fig. 3d-f) measurements. The green lines in Fig. 3 represent simulated daily average concentrations from the modeling study, which will be discussed subsequently. Figure 3 demonstrates that measured daily average $\mathrm{PM}_{10-2.5}$ concentrations have strong temporal variations at each site with episodic high levels. The CV of measured $\mathrm{PM}_{10-2.5}$ concentrations is not less than 1.0 at 22 of 25 sites, ranging from 0.7 to 2.0 (see Table 2). Figure 3 a shows that measured $\mathrm{PM}_{10-2.5}$ concentrations exceeded the level of the $\mathrm{PM}_{10}$ NAAQS (24$\mathrm{h}$ average of $150 \mathrm{\mu g} \mathrm{m}^{-3}$ ) for many days in 2005 in El Paso. This result highlights the necessity to understand the behavior of coarse particles in order to develop mitigation strategies to keep the $\mathrm{PM}_{10}$ concentrations at safe levels.

\subsubsection{Seasonal patterns}

Figure 3 also reveals seasonal patterns. The measured $\mathrm{PM}_{10-2.5}$ concentrations show different seasonal patterns de- pendent on location. At some sites (e.g. Fargo and Fresno, two inland or valley sites influenced by agricultural sources, shown in Fig. $3 \mathrm{c}$ and $\mathrm{f}$ ), the measured concentrations show a seasonal pattern with lower values in winter months. At those sites in the southwestern US and on the west coast (e.g. El Paso West, Seattle, and Riverside shown in Fig. 3a-b, d), the measured $\mathrm{PM}_{10-2.5}$ concentrations seem to be more uniform over the year, with some episodic increased concentrations.

\subsubsection{Weekly patterns}

The red lines in Fig. 4 show one-year average weekly patterns of measured $\mathrm{PM}_{10-2.5}$ concentrations at selected hourly sites. There are primarily three different average weekly patterns of observed $\mathrm{PM}_{10-2.5}$ concentrations at the hourly sites. The first pattern shows that the measured $\mathrm{PM}_{10-2.5}$ concentrations are $\sim 50 \%$ lower for weekends than for weekdays (e.g. the Seattle site shown in Fig. 4a), reflecting significant influences of weekday versus weekend human activities on $\mathrm{PM}_{10-2.5}$ concentrations at these sites. The second weekly pattern, on the contrary, shows that there is little difference in the observed concentrations between weekdays and weekends (e.g. the El Paso West site shown in Fig. 4c). The weekday versus weekend human activities have a negligible impact on observed $\mathrm{PM}_{10-2.5}$ concentrations at these sites. The third pattern, which lies in between the previous two patterns, suggests that human activities have a moderate influence on the observed $\mathrm{PM}_{10-2.5}$ concentrations, with one-year average levels being about $20 \%$ lower during weekends than weekdays (e.g. the Santa Barbara site in Fig. 4b). The patterns are apparently dependent on the relative importance of the weekday versus weekend human activities on $\mathrm{PM}_{10-2.5}$ concentrations compared to other sources.

\subsubsection{Diurnal patterns}

The red lines in Fig. 5a-d show one-year average diurnal patterns of measured $\mathrm{PM}_{10-2.5}$ concentrations at selected hourly sites. The measured concentrations exhibit different diurnal patterns varying with location. Observed $\mathrm{PM}_{10-2.5}$ concentrations at some sites (e.g. see Fig. 5a for the Denver site) show a typical diurnal pattern associated with on-road traffic. There is a rush-hour peak in the morning, followed by a decrease corresponding to a reduced volume of traffic and an increased mixing layer height in the middle of the day. Then there is a late afternoon rush-hour peak and another reduction afterwards. However, the measured patterns at other sites are more complicated with some having significantly bigger afternoon peaks (e.g. Fig. 5 b for El Paso West) but with others having significantly bigger morning peaks (e.g. Fig. 5c for Seattle). The diurnal pattern at the Rapid City site, which is significantly influenced by industrial facilities (Sect. 3.1), is completely different: the concentrations at night are relatively small $\left(15 \mu \mathrm{g} \mathrm{m}^{-3}\right)$, and increase steadily, reaching a maximum value of about $42 \mu \mathrm{g} \mathrm{m}^{-3}$ in the middle of the 

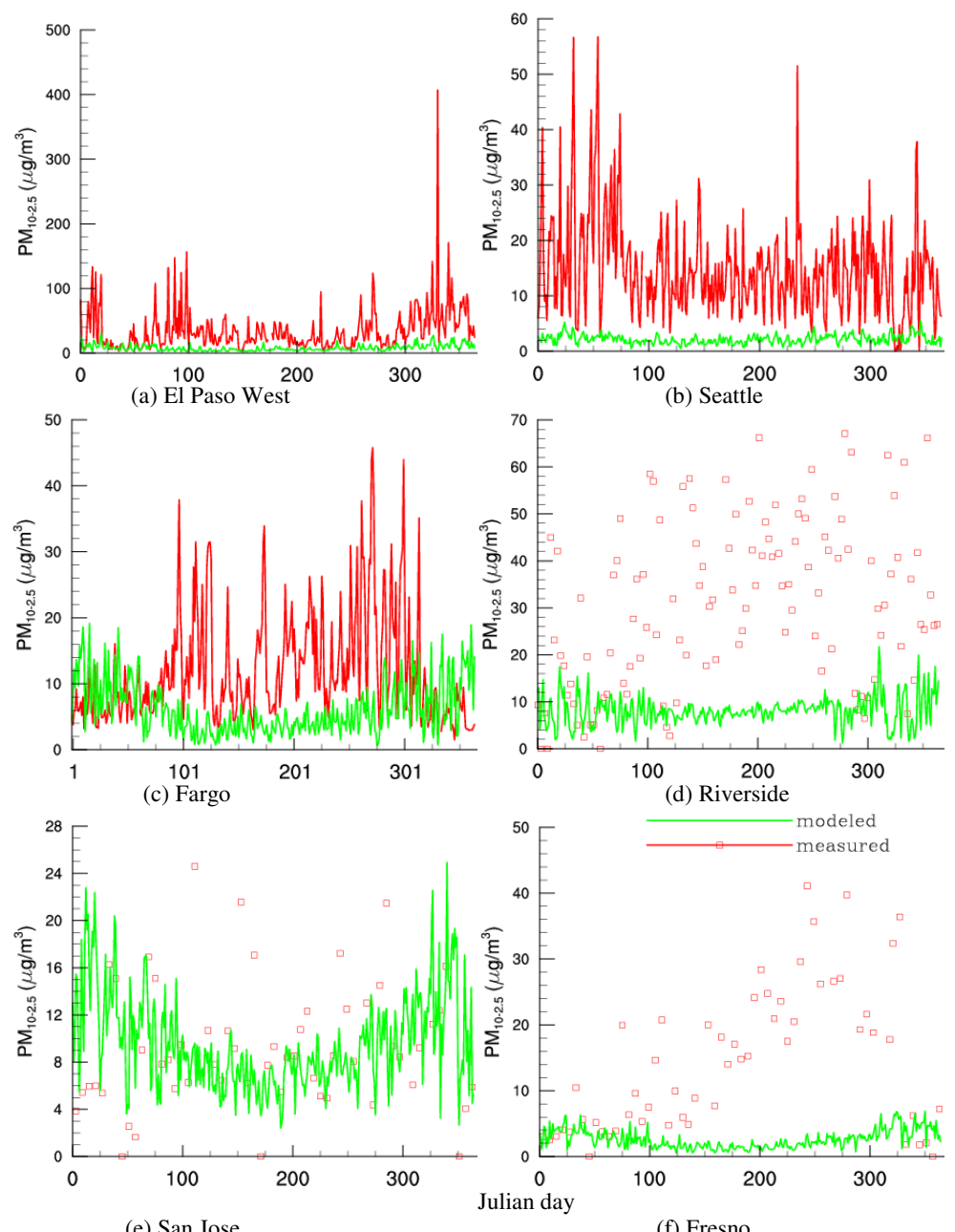

(e) San Jose

(f) Fresno

Fig. 3. Measured (red lines or symbols) and modeled (green lines) daily-average $\mathrm{PM}_{10-2.5}$ concentrations at representative hourly (a-c) and 24-h (d-f) sites. Note that the 24-h measurements were taken every 3 days at the Riverside site (d) but every 6 days at the San Jose (e) and Fresno (f) sites. Note the differences in scale.

day, then decrease gradually to $19 \mu \mathrm{g} \mathrm{m}^{-3}$ in the evening. These different patterns reflect a range of different contributing sources at different locations.

\section{Comparison of observations with model simulations}

\subsection{Model performance for the magnitude of $\mathrm{PM}_{10-2.5}$ concentrations}

In addition to the measured concentrations, Table 2 also shows statistical analyses of CMAQ-predicted $\mathrm{PM}_{10-2.5}$ concentrations. Table 2 reveals that the CMAQ model underestimated annual $\mathrm{PM}_{10-2.5}$ concentrations at all sites except for San Jose, CA, where the agreement between modeled and measured annual average concentrations is the best among all sites. However, the good agreement at the San Jose site is only for the annual mean concentration; the model failed to reproduce the seasonal pattern at this site (see Sect. 4.3.2). The mean ratio of measured to modeled annual $\mathrm{PM}_{10-2.5}$ concentrations, averaged across all sites, is more than 4, with the maximum ratio of 27 at the Nogales site in the southern Arizona. While CMAQ generally underestimated $\mathrm{PM}_{10-2.5}$ concentrations at almost all sites, there are variations in model performance at different locations. While the modeled and measured annual mean concentrations agree within a factor of two at 16 sites, 20 sites have measured annual mean concentrations that are more than four times higher than modeled values (Table 2). Among these 20 sites, 14 sites have observed annual mean concentrations being more than five times higher than simulated levels. The lower modeled concentrations are likely due to the omission or significant underestimation (or a combination of both) of important emission sources in the inventory. Further discussions on the causes for the lower modeled concentrations are in Sect. 5. 


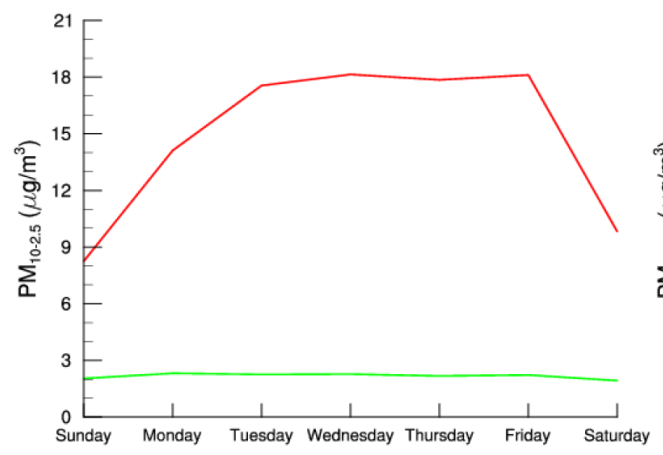

(a) Seattle

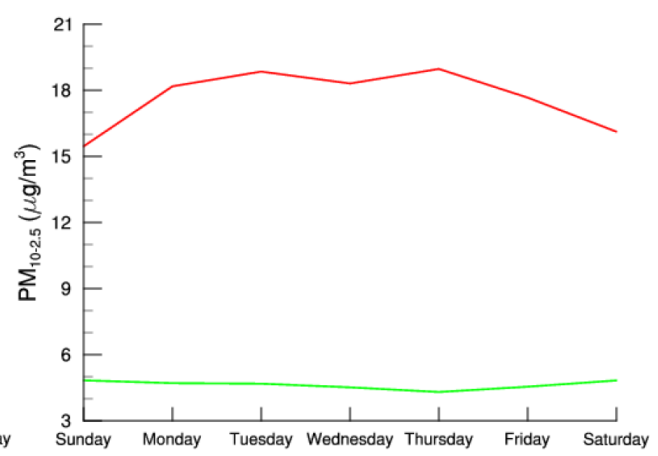

(b) Santa Barbara

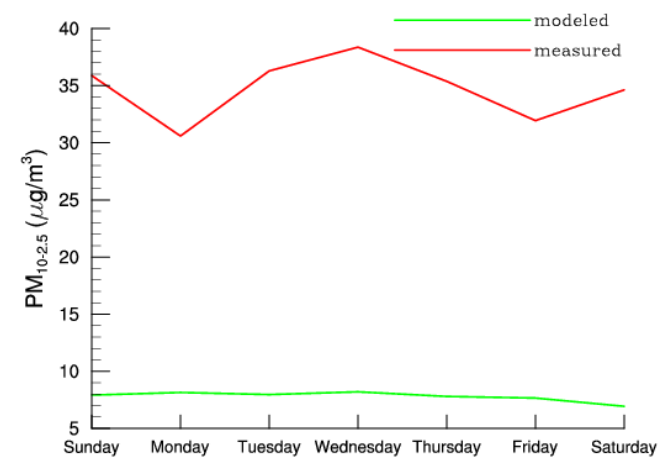

(c) El Paso West

Fig. 4. One-year average weekly patterns of measured (red lines) and modeled (green lines) $\mathrm{PM}_{10-2.5}$ concentrations at representative hourly sites. Note the differences in scale.

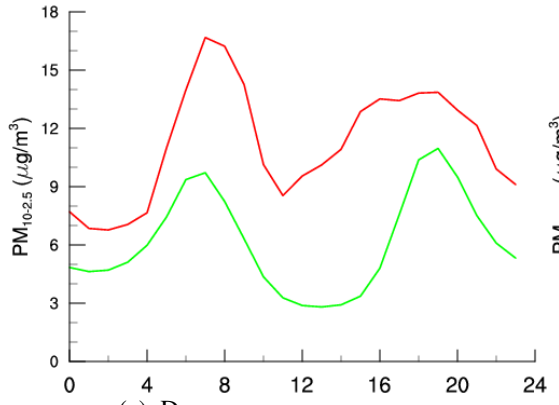

(a) Denver

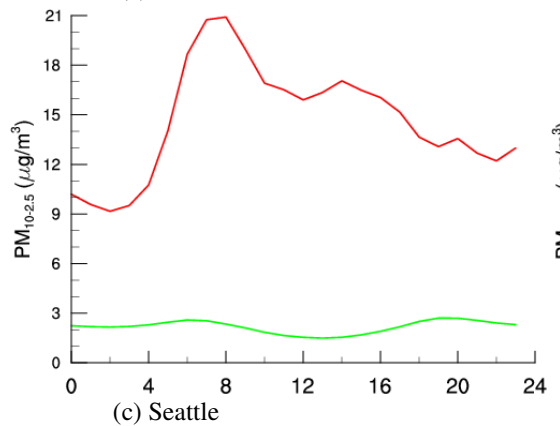

(c) Seattle

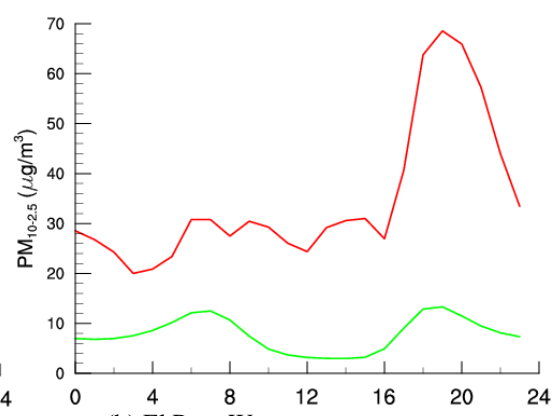

(b) El Paso West

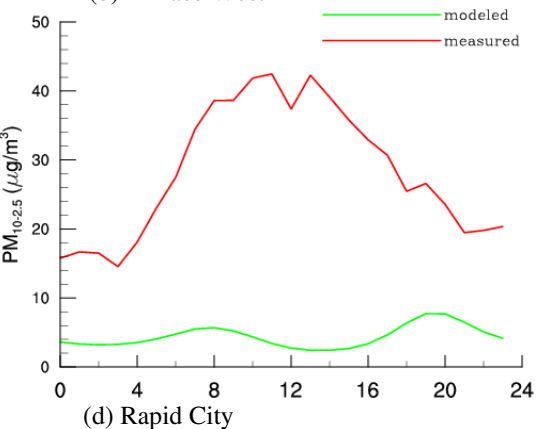

(d) Rapid City

Fig. 5. One-year average diurnal patterns of measured (red lines) and modeled (green lines) $\mathrm{PM}_{10-2.5}$ concentrations at selected hourly sites. Note the differences in scale. 
Model performance metrics were calculated using modeled $\left(C_{\mathrm{m}}\right)$ and observed $\left(C_{\mathrm{o}}\right)$ concentrations as well as the number of available concentration pairs $(N)$ at a location (Boylan and Russell, 2006):

Mean fractional bias:

$\mathrm{MFB}=\frac{1}{N} \sum_{i=1}^{N} \frac{\left(C_{\mathrm{m}}-C_{\mathrm{o}}\right)}{\left(C_{\mathrm{o}}+C_{\mathrm{m}} / 2\right)}$

Mean fractional error:

$\mathrm{MFE}=\frac{1}{N} \sum_{i=1}^{N} \frac{\left|C_{\mathrm{m}}-C_{\mathrm{o}}\right|}{\left(C_{\mathrm{o}}+C_{\mathrm{m}} / 2\right)}$

Normalized mean bias:

$\mathrm{NMB}=\frac{\sum_{i=1}^{N}\left(C_{\mathrm{m}}-C_{\mathrm{o}}\right)}{\sum_{i=1}^{N} C_{\mathrm{o}}}$

Normalized mean error:

$\mathrm{NME}=\frac{\sum_{i=1}^{N}\left|C_{\mathrm{m}}-C_{\mathrm{o}}\right|}{\sum_{i=1}^{N} C_{\mathrm{o}}}$

Mean bias:

$\mathrm{MB}=\frac{1}{N} \sum_{i=1}^{N}\left(C_{\mathrm{m}}-C_{\mathrm{o}}\right)$

Mean error:

$\mathrm{ME}=\frac{1}{N} \sum_{i=1}^{N}\left|C_{\mathrm{m}}-C_{\mathrm{o}}\right|$

These metrics were recommended by the US EPA for model performance of ozone and $\mathrm{PM}_{2.5}$ predictions. Since research on $\mathrm{PM}_{10-2.5}$ has been very limited and the present study, to our knowledge, represents the first regional modeling study of $\mathrm{PM}_{10-2.5}$, Table 3 provides the first calculated performance metrics for $\mathrm{PM}_{10-2.5}$.

Except for sea salt and point source emissions, the applied $\mathrm{PM}_{10-2.5}$ emissions from other sources were provided as annual totals at the county level in the inventory; in the simulations these emissions were spatially allocated into userspecified grids using surrogate data, and temporally allocated into hourly values using monthly, weekly, and diurnal emission profiles. In the following sections we compare the modeled and observed spatial and temporal patterns of $\mathrm{PM}_{10-2.5}$ concentrations to provide insights for the spatial and temporal allocation in the model.

\subsection{Spatial allocation}

Strong variability of ratio of measured to modeled $\mathrm{PM}_{10-2.5}$ concentrations across the western United States mentioned

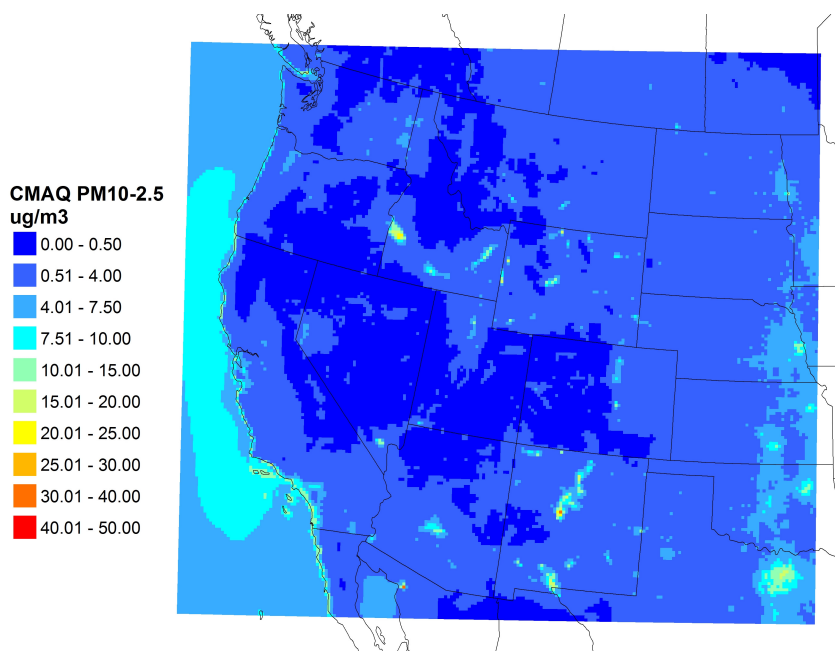

Fig. 6. Modeled annual mean $\mathrm{PM}_{10-2.5}$ concentrations in $\mu \mathrm{g} \mathrm{m}^{-3}$.

earlier (also shown in Table 2) means that there are differences in spatial patterns of measured and modeled concentrations. Figure 6 presents the modeled one-year average $\mathrm{PM}_{10-2.5}$ concentrations for the study domain. Comparison of Fig. 6 to Fig. 2 confirms that the CMAQ model underpredicts the magnitude of $\mathrm{PM}_{10-2.5}$ concentrations at almost all sites across the domain. This comparison and Table 2, however, reveal that the CMAQ model captured some characteristics of spatial distribution of $\mathrm{PM}_{10-2.5}$ concentrations. For example, the model accurately predicted the ranking of the three sites from most to least polluted within an urban area: the modeled annual mean concentration is higher at the Albuquerque South site than at the Albuquerque North site, with the level at the Albuquerque East site being lowest. The ratio of modeled annual mean concentrations at the Rapid City site $\left(4.4 \mu \mathrm{m} \mathrm{m}^{-3}\right)$ versus the Wind Cave National Park site $\left(0.6 \mu \mathrm{m} \mathrm{m}^{-3}\right)$ is about 7.3 , similar to 10 , the ratio of measured concentrations $\left(28.4 \mu \mathrm{m} \mathrm{m}^{-3}\right.$ versus $\left.2.8 \mu \mathrm{m} \mathrm{m}^{-3}\right)$, although the model significantly underestimated the concentrations at these sites.

The model also failed to reproduce many characteristics of the observed spatial patterns. For example, the measured annual mean concentration at the Nogales site, Arizona $\left(49.4 \mu \mathrm{m} \mathrm{m}^{-3}\right)$, where shrublands dominate (Fig. 1) with very low soil moistures (Table 1), is the highest and much higher than that at the Thompson Lake site, ND $\left(6.7 \mu \mathrm{m} \mathrm{m}^{-3}\right)$, where croplands dominate (Fig. 1) with much higher soil moistures (Table 1). However, the modeled annual means at these two sites are the same $\left(1.8 \mu \mathrm{m} \mathrm{m}^{-3}\right)$. Also, the observed concentrations at the El Paso North and El Paso West sites are the same $\left(34.8 \mu \mathrm{m} \mathrm{m}^{-3}\right)$, but the modeled annual mean is much higher at the former site $\left(18.4 \mu \mathrm{m} \mathrm{m}^{-3}\right)$ than the latter site $\left(7.8 \mu \mathrm{m} \mathrm{m}^{-3}\right)$. The model also reversed the annual mean concentration ranking of many other sites. The observed annual mean concentration at the E Scottsdale site 
Table 3. Performance Metrics.

\begin{tabular}{|c|c|c|c|c|c|c|c|c|c|}
\hline Site Name & AQS Site ID & Latitude & Longitude & $\begin{array}{r}\text { Mean Bias } \\
\left(\mu \mathrm{g} \mathrm{m}^{-3}\right)\end{array}$ & $\begin{array}{r}\text { Mean Error } \\
\left(\mu \mathrm{g} \mathrm{m}^{-3}\right)\end{array}$ & $\begin{array}{r}\text { Mean } \\
\text { Fractional } \\
\text { Bias }(\%)\end{array}$ & $\begin{array}{r}\text { Mean } \\
\text { Fractional } \\
\text { Error }(\%)\end{array}$ & $\begin{array}{r}\text { Normalized } \\
\text { Mean Bias } \\
(\%)\end{array}$ & $\begin{array}{r}\text { Normalized } \\
\text { Mean Error } \\
(\%)\end{array}$ \\
\hline Nogales, AZ & 40230004 & 31.337 & -110.937 & -48 & 48 & -82 & 89 & -96 & 97 \\
\hline East Sacramento, CA & 60670006 & 38.614 & -121.367 & -7 & 9 & -18 & 76 & -60 & 82 \\
\hline Santa Barbara, CA & 60830011 & 34.428 & -119.690 & -13 & 14 & -50 & 67 & -73 & 78 \\
\hline Denver, $\mathrm{CO}$ & 80310002 & 39.751 & -104.988 & -6 & 9 & -4 & 69 & -49 & 73 \\
\hline Coeur D'Alene, ID & 160550006 & 47.682 & -116.766 & -3 & 7 & 10 & 69 & -38 & 82 \\
\hline NW Pocatello, ID & 160770011 & 42.913 & -112.536 & -11 & 13 & 14 & 97 & -74 & 92 \\
\hline Pinehurst, ID & 160790017 & 47.536 & -116.237 & -7 & 8 & -26 & 93 & -86 & 91 \\
\hline Albuquerque East, NM & 350010019 & 35.107 & -106.564 & -2 & 8 & 17 & 68 & -19 & 81 \\
\hline Albuquerque South, NM & 350010029 & 35.017 & -106.657 & -10 & 16 & 2 & 62 & -46 & 75 \\
\hline Albuquerque North, NM & 350011013 & 35.193 & -106.614 & -7 & 13 & 7 & 63 & -39 & 74 \\
\hline El Paso North (Anthony), NM & 350130016 & 32.004 & -106.599 & -16 & 23 & -18 & 49 & -47 & 66 \\
\hline El Paso West, NM & 350130017 & 31.796 & -106.558 & -27 & 29 & -41 & 63 & -77 & 82 \\
\hline Sandoval, NM & 350439004 & 35.615 & -106.724 & -27 & 29 & 0 & 102 & -85 & 93 \\
\hline Crop\&River, ND & 380130002 & 48.990 & -102.782 & -5 & 6 & -27 & 61 & -58 & 79 \\
\hline Thompson Lake, ND & 380130004 & 48.642 & -102.402 & -5 & 5 & -46 & 62 & -72 & 81 \\
\hline Fargo, ND & 380171004 & 46.934 & -96.855 & -6 & 9 & -23 & 57 & -49 & 77 \\
\hline Overlook, ND & 380530002 & 47.581 & -103.300 & -5 & 5 & -59 & 75 & -83 & 86 \\
\hline Wind Cave National Park, SD & 460330132 & 43.558 & -103.484 & -2 & 2 & 15 & 108 & -77 & 92 \\
\hline Badlands, SD & 460710001 & 43.746 & -101.941 & -4 & 4 & -16 & 95 & -83 & 91 \\
\hline Rapid City, SD & 461030020 & 44.087 & -103.274 & -24 & 25 & -36 & 71 & -84 & 90 \\
\hline El Paso1, TX & 481410037 & 31.768 & -106.501 & -17 & 20 & -32 & 62 & -69 & 79 \\
\hline El Paso East, TX & 481410055 & 31.747 & -106.403 & -24 & 25 & -54 & 72 & -83 & 86 \\
\hline Seattle, WA & 530330057 & 47.563 & -122.341 & -13 & 13 & -56 & 79 & -85 & 87 \\
\hline South Seattle, WA & 530332004 & 47.386 & -122.232 & -7 & 8 & -35 & 79 & -79 & 84 \\
\hline Spokane, WA & 530630016 & 47.661 & -117.358 & -12 & 14 & -17 & 86 & -75 & 88 \\
\hline Average of 25 stations & & & & -12 & 15 & -23 & 75 & -67 & 83 \\
\hline
\end{tabular}

$\left(39.9 \mu \mathrm{m} \mathrm{m}^{-3}\right)$ is much higher than that at the $\mathrm{N}$ Phoenix site $\left(19.4 \mu \mathrm{m} \mathrm{m}^{-3}\right)$; however, the modeled value is lower at the former site $\left(8.7 \mu \mathrm{m} \mathrm{m}^{-3}\right)$ than the latter site $\left(10.0 \mu \mathrm{m} \mathrm{m}^{-3}\right)$. These sites are located within $22 \mathrm{~km}$ of one another. Similarly, the observed annual mean concentration is more than 2 times higher at the North Riverside site, CA $\left(25.6 \mu \mathrm{m} \mathrm{m}^{-3}\right)$ than at the Anaheim site, CA $\left(11.4 \mu \mathrm{m} \mathrm{m}^{-3}\right)$, which are $51 \mathrm{~km}$ apart, but the modeled value is almost two times higher at the latter site $\left(9.5 \mu \mathrm{m} \mathrm{m}^{-3}\right)$ than at the former site $\left(5.0 \mu \mathrm{m} \mathrm{m}^{-3}\right)$. Although the observed annual mean concentration is more than three times higher at the Sandoval site, $\mathrm{NM}\left(31.4 \mu \mathrm{m} \mathrm{m}^{-3}\right)$ than at the Albuquerque East site, NM $\left(10.0 \mu \mathrm{m} \mathrm{m}^{-3}\right)$, the modeled value is much lower at the former site $\left(4.7 \mu \mathrm{m} \mathrm{m}^{-3}\right)$ than at the latter site $\left(8.1 \mu \mathrm{m} \mathrm{m}^{-3}\right)$. These results may be caused by variable emission underestimations in the inventory across the domain; another possibility is the inaccurate spatial allocation in the emission modeling system.

\subsection{Temporal allocation}

\subsubsection{Temporal variability}

Figure 3 and Table 2 show that the modeled daily average $\mathrm{PM}_{10-2.5}$ concentrations are less variable than measurements at almost all sites with average ratio of measurement $\mathrm{CV}$ over model $\mathrm{CV}$ being more than 1.5 . We suggest two plausible explanations. First, the modeling system, as mentioned, allocates annual emissions into hourly values using monthly, weekly and diurnal profiles. This approach does not have the representation for the strong episodic nature of $\mathrm{PM}_{10-2.5}$ emissions such as fugitive dust from construction and agricultural tilling that can be affected by several factors including human operation and wind speed. Second, the measured concentrations were obtained at a specific location on the surface, whereas the modeled concentrations were values averaged over a box over a $12 \times 12 \mathrm{~km}$ grid cell with a height of approximately $38 \mathrm{~m}$ in the first model layer. This spatially, especially vertically averaging might have lead to smoother variability of modeled $\mathrm{PM}_{10-2.5}$ concentrations compared to the observations. Figure $3 \mathrm{a}$ shows that the modeling system did not capture very high concentrations in $\mathrm{PM}_{10-2.5}$ episodes, in which the measured $\mathrm{PM}_{10-2.5}$ concentrations alone exceeded the level of the $\mathrm{PM}_{10}$ NAAQS in El Paso. Since this modeling system is used for air quality management and forecasts, this inability to accurately simulate the high episodic concentrations can cause serious problems in such important issues as air quality advisory issuances and health risk assessments.

\subsubsection{Seasonal allocation}

While the measured concentrations show different seasonal patterns dependent on location as mentioned in Sect. 3.2.2, 


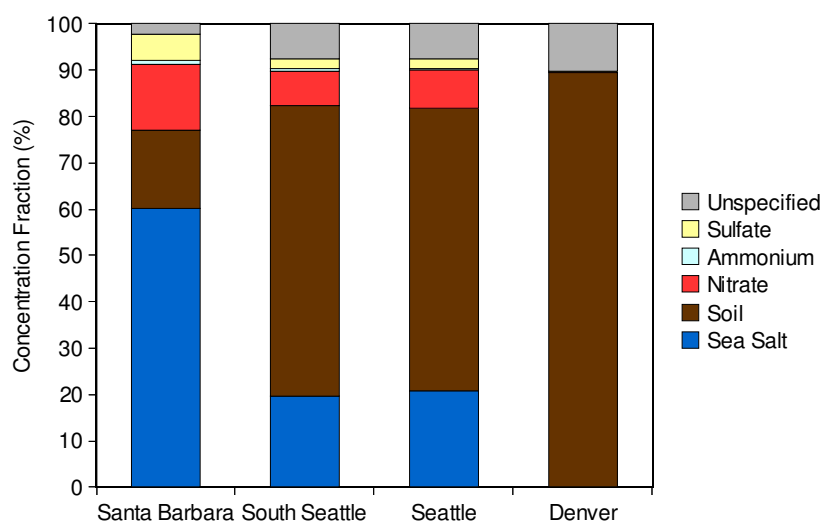

Fig. 7. Modeled concentration fractions of $\mathrm{PM}_{10-2.5}$ chemical components at selected sites.

the green lines in Fig. 3 show that the modeled $\mathrm{PM}_{10-2.5}$ concentrations exhibit the same seasonal pattern at all sites with somewhat higher concentrations in winter months. Even at the San Jose site, CA, where the best agreement was found between the modeled and measured annual average concentrations, the seasonal patterns are clearly different: the model significantly under-predicted $\mathrm{PM}_{10-2.5}$ concentrations in warm months, whereas it overestimated concentrations in winter months. The comparisons between modeled and measured daily concentration time series suggest that the modeling system needs to be improved to better simulate seasonal patterns.

\subsubsection{Weekly allocation}

While there are three distinct weekly patterns of measured concentrations (red lines in Fig. 4), we found that the modeled weekly patterns for all sites are similar; there is little difference between modeled weekday and weekend concentrations as shown by green lines in Fig. 4a-c. Figure $4 a-c$ further confirms that CMAQ significantly underestimates $\mathrm{PM}_{10-2.5}$ concentrations at these sites. The comparisons between modeled and measured weekly patterns suggest that the-day-of-week allocation needs to be improved to reflect variable influences of weekday versus weekend human activities at different locations.

\subsubsection{Diurnal allocation}

Figure 5a-d show that CMAQ not only under-predicts the magnitude of $\mathrm{PM}_{10-2.5}$ concentrations, but fails to duplicate the diurnal patterns at many locations. While the measured concentrations exhibit distinct diurnal patterns varying with location, modeled concentrations show the same diurnal pattern with two similar peaks (one in the morning and the other in the afternoon) at all sites. This means that the diurnal allocation in the modeling system is too idealized to reflect complex patterns at different locations.

\section{Discussion}

The CMAQ model not only under-predicted the magnitude and variability of $\mathrm{PM}_{10-2.5}$ concentrations, but also failed to duplicate the spatial as well as seasonal, weekly and diurnal patterns. The causes for the underestimated concentrations in the model may differ based on different major contributing sources. For example, our results show that the measured concentrations are very high at sites in the southwestern US, such as El Paso West (Figs. 3a, 4c, and 5b). Since the area is dominated by shrublands, barren or sparse vegetation land cover with very dry soils (Fig. 1) - ideal conditions for high wind-blown dust - the high concentrations may be dominantly contributed by geogenic and other fugitive dust sources. This suggests that the underestimated concentrations in this area are caused in part by the omission of wind-blown dust in the inventory, which may also contribute to the incorrect seasonality of modeled concentrations. Still, we cannot rule out the possibility of significant under-estimation of sources such as unpaved road dust and construction, which will also be important in regions with dry soils. Some sites (e.g. Seattle) have very strong anthropogenic influence indicated by large weekday-weekend difference in observed $\mathrm{PM}_{10-2.5}$ concentrations (Sect. 3.2.3); therefore, the inclusion of natural emission sources such as wind-blown dust alone could not lead to model reconciliation with measurements. Thus, efforts should be made to improve emissions associated with human activities at these sites.

The three costal sites with hourly observations (i.e. Santa Babara, South Seattle, and Seattle) are expected to have a significant marine influence. Sea salt contributes considerably to the modeled concentrations at the Santa Babara $(\sim 60 \%)$, South Seattle $(\sim 20 \%)$, and Seattle $(\sim 21 \%)$ sites, as shown in Fig. 7, which shows modeled concentration fractions of coarse particle components (i.e. sea salt, soil dust, nitrate, ammonium, sulfate, and unspecified particles) at these three coastal sites and the Denver site. Since modeled concentrations at these three coastal sites were much lower than measurements, it is possible that the sea salt concentrations might still have been underestimated by the CMAQ model. The large weekday-weekend difference in $\mathrm{PM}_{10-2.5}$ concentrations in Seattle, mentioned earlier, suggests that some anthropogenic sources such as construction and on-road traffic might also have been under-estimated. Modeled sea salt only affects a narrow coastal zone and over the ocean (not shown). The inland sites were dominated by soil dust (e.g. as shown by Fig. 7 for the Denver site).

Recent studies show that coarse particles contain significant organics (Cheung et al., 2011; Edgerton et al., 2009); however, Fig. 7 shows that the CMAQ model does not explicitly simulate organic materials in coarse particles. Therefore the omission of organic sources, such as primary biological particles and humic-like substances from soils, is another possible cause for lower modeled concentrations compared to measurements. The organic components of 
Table 4. Correlations between $\mathrm{PM}_{10-2.5}$ concentrations and wind speed, boundary layer height, and surface moisture.

\begin{tabular}{lcrrr}
\hline \multirow{2}{*}{ Site Name } & AQS Site ID & \multicolumn{2}{c}{ Correlation coefficient of PM $_{10-2.5}$ with following variables } \\
\cline { 3 - 5 } & & Wind speed & Boundary layer height & Soil moisture \\
\hline Nogales, AZ & 40230004 & -0.13 & -0.30 & -0.10 \\
East Sacramento, CA & 60670006 & 0.18 & 0.10 & -0.38 \\
Santa Barbara, CA & 60830011 & 0.01 & 0.16 & -0.28 \\
Denver, CO & 80310002 & 0.02 & -0.06 & -0.17 \\
Coeur D'Alene, ID & 160550006 & 0.06 & 0.12 & -0.16 \\
NW Pocatello, ID & 160770011 & 0.10 & -0.03 & -0.21 \\
Pinehurst, ID & 160790017 & 0.00 & 0.01 & -0.17 \\
Albuquerque East, NM & 350010019 & 0.13 & 0.07 \\
Albuquerue South & 350010029 & 0.12 & 0.03 & -0.10 \\
Albuquerque North, NM & 350011013 & -0.02 & -0.05 & -0.20 \\
El Paso North (Anthony), NM & 350130016 & 0.16 & -0.01 & -0.09 \\
El Paso West, NM & 350130017 & 0.12 & -0.04 & -0.07 \\
Sandoval, NM & 350439004 & -0.02 & -0.02 & -0.22 \\
Crop\&River, ND & 380130002 & 0.07 & 0.14 & -0.32 \\
Thompson Lake, ND & 380130004 & 0.14 & 0.22 & -0.37 \\
Fargo, ND & 380171004 & 0.08 & 0.08 & -0.36 \\
Overlook, ND & 380530002 & 0.24 & 0.16 & -0.31 \\
Wind Cave National Park, SD & 460330132 & -0.02 & -0.12 \\
Badlands, SD & 460710001 & 0.15 & 0.03 & -0.06 \\
Rapid City, SD & 461030020 & 0.22 & 0.07 & -0.10 \\
El Paso1, TX & 481410037 & 0.14 & 0.13 & -0.09 \\
El Paso East, TX & 481410055 & 0.14 & -0.01 & -0.09 \\
Seattle, WA & 530330057 & 0.04 & -0.02 & -0.12 \\
South Seattle, WA & 530332004 & -0.03 & -0.04 & -0.21 \\
Spokane, WA & 530630016 & 0.00 & 0.03 & -0.15 \\
\hline & & & -0.05 &
\end{tabular}

coarse particles have implications for health risk assessments and atmospheric chemistry, thus improvements should be made to include organics in coarse particles in the future.

Significant concentration differences and small correlations were observed between some proximate sites (Sect. 3.1), suggesting that $\mathrm{PM}_{10-2.5}$ can be largely influenced by local factors. Therefore, the exact spatial information of emission sources becomes more important for $\mathrm{PM}_{10-2.5}$. The current $\mathrm{PM}_{10-2.5}$ emissions from such sources as construction, road, and agricultural tiling are provided at the county-level that are ultimately spatially allocated into user-defined grids during simulations using surrogate data. It may be necessary to further specify the detailed spatial information of coarse PM sources in future emission inventories and model developments.

While modeled $\mathrm{PM}_{10-2.5}$ concentrations show the same seasonal, weekly, and diurnal pattern regardless of location, the observed patterns are more complex; no consistent patterns were observed at all sites, indicative of a variety of contributing sources and their relative importance. Therefore the current temporal allocation approach in the model framework needs to be improved since it is too simplified to track the real patterns at different locations.
Correlations between $\mathrm{PM}_{10-2.5}$ concentrations and wind speed, boundary layer height, and surface moisture output from MM5 were calculated for all hourly sites (Table 4). $\mathrm{PM}_{10-2.5}$ concentrations are positively correlated with wind speed at most sites (18 of 25 sites), with the greatest correlations occur at the Overlook site $(r=0.24)$, ND, and the Rapid City site $(r=0.22)$, SD. However, zero or negative correlations were found at a few other sites (Table 4), with $r=-0.13$ at the Nogales site, AZ. This result suggests that $\mathrm{PM}_{10-2.5}$ concentrations are affected by factors other than wind speed. Although in a region where dust is expected to influence the coarse PM concentrations, the Nogales site in Arizona is unique in that it is located near a roadway and a busy border crossing between the US and Mexico. We expect that the traffic and anthropogenic activity near this site to control $\mathrm{PM}_{10-2.5}$ emissions and concentrations. The correlation between $\mathrm{PM}_{10-2.5}$ concentrations and the boundary layer height is -0.30 at the Nogales site, AZ, implying higher concentrations may be partly caused by lower boundary height (Table 4). $\mathrm{PM}_{10-2.5}$ concentrations are negatively correlated with boundary layer height at only 11 of 25 sites. At the other 14 sites, positive correlations were found between the $\mathrm{PM}_{10-2.5}$ concentrations and the boundary layer height. This result reflects the complex influences 
on $\mathrm{PM}_{10-2.5}$ concentrations by the boundary layer height and other possible factors as well as their interactions. $\mathrm{PM}_{10-2.5}$ concentrations are negatively correlated with soil moisture at all investigated sites (Table 4), indicating that high $\mathrm{PM}_{10-2.5}$ concentrations are correlated to lower soil moisture. Since less dust can be emitted into the atmosphere in wet conditions and airborne particles can be washed out at precipitation events, higher concentrations of dust are expected under drier conditions.

Chemical and biological analyses of measured $\mathrm{PM}_{10-2.5}$ can be employed to quantify percentage contributions from different sources at the ambient measurement sites; however, little chemical or biological speciation data exists for $\mathrm{PM}_{10-2.5}$. By taking an approach that combines both mass concentration observations and model simulations, this study has improved our understanding of the sources and behavior of $\mathrm{PM}_{10-2.5}$ concentrations at a regional scale in the western United States, and has provided insights into future developments of models that simulate atmospheric $\mathrm{PM}_{10-2.5}$ emissions, transport, and fate.

Measurement of all of criteria air pollutants is required by law. To help meet this requirement, a Federal Reference Method (FRM) and Federal Equivalency Methods (FEM) for each have been established and are documented in the Code of Federal Regulations (CFR). The FRM and FEM requirements are stringent with lengthy quality control and quality assurance protocols for each pollutant. The end result is high quality measurement data for each pollutant being reported in the AQS. AQS data have been used successfully by numerous studies (e.g. Chang et al., 2012; Drury et al., 2010; Jensen et al., 2009; Sampson et al., 2011; van Donkelaar et al., 2006; Zhang et al., 2006). FRM and FEM for $\mathrm{PM}_{10-2.5}$ were not established until 2007 and, as such, there are no $\mathrm{PM}_{10-2.5}$ mass concentrations in the AQS for our study year of 2005. The FRM for $\mathrm{PM}_{10-2.5}$ involves subtraction of low volume FRM $\mathrm{PM}_{2.5}$ mass concentration from a co-located low volume FRM $\mathrm{PM}_{10}$ mass concentration (for more details see CFR 40 Part 50 Appendix O). Our approach here was to use the best possible substitute. We used subtraction of collocated FRM PM 2.5 mass concentration from FRM $\mathrm{PM}_{10}$ mass concentration, without distinction of sample volume. This approach will likely increase the uncertainty associated with the resulting $\mathrm{PM}_{10-2.5}$ mass concentrations as compared to the FRM PM $10-2.5$. Additionally, this approach may potentially introduce a small bias associated with how volatile components are assessed. However, the magnitude of the potential bias and uncertainty associated with our approach is relatively small compared to the big differences between measured and modeled $\mathrm{PM}_{10-2.5}$ concentrations (US EPA, 2004, 2009). In other words, the uncertainties of the measurements cannot affect our conclusion that the modeling system significantly underpredicted $\mathrm{PM}_{10-2.5}$ concentrations across the western United States.

\section{Summary and conclusion}

We investigated the characteristics of observed coarse PM in the western US, and compared CMAQ predictions to the observations. The observed concentrations showed a spatial pattern that could be explained in part with the distributions of land use and soil moistures. The highest concentrations were found in the southwestern US, where sparse vegetation, open shrublands or barren lands dominate with lower soil moistures, whereas the lowest concentrations occurred in areas dominated by grasslands, forest, or croplands with higher soil moistures. Observed concentrations show different seasonal, weekly, and diurnal patterns at different locations across the western United States, reflecting different contributing sources and their relative importance dependent on locations. CMAQ significantly under-predicted $\mathrm{PM}_{10-2.5}$ concentrations. The under-prediction was likely due to omission of sources such as pollen, bacteria, fungal spores, and especially, geogenic dust, as well as under-estimation of other significant source types. CMAQ also failed to reproduce their spatial as well as seasonal, weekly, and diurnal patterns. Unlike observations, the modeled concentrations show similar seasonal, weekly, and diurnal pattern across the entire domain. CMAQ does not include organics in $\mathrm{PM}_{10-2.5}$, which recent measurements show to be a significant component. In this study we identified some important gaps for future developments of coarse PM models and emission inventories.

Acknowledgements. This work is supported by the US Environmental Protection Agency (STAR award \# 834552). We thank Nick Mangus for his help with AQS data. Thanks also go to Bradley L. Rink for providing us with $\mathrm{PM}_{10}$ and $\mathrm{PM}_{2.5}$ data for the Denver site. The National Center for Atmospheric Research is operated by the University Corporation for Atmospheric Research under sponsorship of the National Science Foundation.

Edited by: W. Birmili

\section{References}

Baldasano, J. M., Pay, M. T., Jorba, O., Gasso, S., and JimenezGuerrero, P.: An annual assessment of air quality with the CALIOPE modeling system over Spain, Sci. Total Environ., 409, 2163-2178, 2011.

Birmili, W., Schepanski, K., Ansmann, A., Spindler, G., Tegen, I., Wehner, B., Nowak, A., Reimer, E., Mattis, I., Müller, K., Brüggemann, E., Gnauk, T., Herrmann, H., Wiedensohler, A., Althausen, D., Schladitz, A., Tuch, T., and Löschau, G.: A case of extreme particulate matter concentrations over Central Europe caused by dust emitted over the southern Ukraine, Atmos. Chem. Phys., 8, 997-1016, doi:10.5194/acp-8-997-2008, 2008.

Boylan, J. W. and Russell, A. G.: PM and light extinction model performance metrics, goals, and criteria for three-dimensional air quality models, Atmos. Environ., 40, 4946-4959, 2006. 
Branis, M., Vyskovska, J., Maly, M., and Hovorka, J.: Association of size-resolved number concentrations of particulate matter with cardiovascular and respiratory hospital admissions and mortality in Prague, Czech Republic, Inhal. Toxicol., 22, 21-28, 2010.

Brunekreef, B. and Forsberg, B.: Epidemiological evidence of effects of coarse airborne particles on health, Eur. Resp. J., 26, 309-318, 2005.

Byun, D. W. and Schere, K. L.: Review of the governing equations, computational algorithms, and other components of the Models3 Community Multiscale Air Quality (CMAQ) modeling system, Appl. Mech. Rev., 56, 51-77, 2006.

Carlton, A. G., Turpin, B. J., Altieri, K. E., Seitzinger, S. P., Mathur, R., Roselle, S. J., and Weber, R. J.: CMAQ model performance enhanced when in-cloud secondary organic aerosol is included: Comparisons of organic carbon predictions with measurements, Environ. Sci. Technol., 42, 8798-8802, 2008.

Carlton, A. G., Bhave, P. V., Napelenok, S. L., Edney, E. D., Sarwar, G., Pinder, R. W., Pouliot, G. A., and Houyoux, M.: Model representation of secondary organic aerosol in CMAQv4.7, Environ. Sci. Technol., 44, 8553-8560, 2010.

Chang, H. H., Reich, B. J., and Miranda, M. L.: Time-to-event analysis of fine particle air pollution and preterm birth: results from North Carolina, 2001-2005, Am. J. Epidemiol., 175, 9198, 2012.

Cheung, K., Daher, N., Kam, W., Shafer, M. M., Ning, Z., Schauer, J. J., and Sioutas, C.: Spatial and temporal variation of chemical composition and mass closure of ambient coarse particulate matter $\left(\mathrm{PM}_{10-2.5}\right)$ in the Los Angeles area, Atmos. Environ., 45, 2651-2662, 2011.

Chuang, M., Zhang, Y., and Kang, D.: Application of WRF/ChemMADRID for real-time air quality forecasting over the southeastern United States, Atmos. Environ., 45, 6241-6250, 2011.

Clements, N., Piedrahita, R., Ortega, J., Peel, J. L., Hannigan, M., Miller, S. L., and Milford, J. B.: Characterization and nonparametric regression of rural and urban coarse particulate matter mass concentrations in northeastern Colorado, Aerosol. Sci. Technol., 46, 108-123, 2012.

DeMott, P., Sassen, K., Poellot, M., Baumgardner, D., Rogers, D., Brooks, S., Prenni, A., and Kreidenweis, S.: African dust aerosols as atmospheric ice nuclei, Geophys. Res. Lett., 30, 1732, doi:10.1029/2003GL017410, 2003.

Drury, E., Jacob, D. J., Spurr, R. J. D., Wang, J., Shinozuka, Y., Anderson, B. E., Clarke, A. D., Dibb, J., McNaughton, C., and Weber, R.: Synthesis of satellite (MODIS), aircraft (ICARTT), and surface (IMPROVE, EPA-AQS, AERONET) aerosol observations over eastern North America to improve MODIS aerosol retrievals and constrain surface aerosol concentrations and sources, J. Geophys. Res.-Atmos., 115, D14204, doi:10.1029/2009JD012629, 2010.

Dudhia, J.: Numerical study of convection observed during the winter monsoon experiment using a mesoscale two-dimensional model, J. Atmos. Sci., 46, 3077-3107, 1989.

Edgerton, E. S., Casuccio, G. S., Saylor, R. D., Lersch, T. L., Hartsell, B. E., Jansen, J. J., and Hansen, D. A.: Measurements of OC and EC in coarse particulate matter in the southeastern United States, J. Air Waste Manage., 59, 78-90, 2009.

Foley, K. M., Roselle, S. J., Appel, K. W., Bhave, P. V., Pleim, J. E., Otte, T. L., Mathur, R., Sarwar, G., Young, J. O., Gilliam, R. C., Nolte, C. G., Kelly, J. T., Gilliland, A. B., and Bash, J.
O.: Incremental testing of the Community Multiscale Air Quality (CMAQ) modeling system version 4.7, Geosci. Model Dev., 3, 205-226, doi:10.5194/gmd-3-205-2010, 2010.

Harrison, R. M., Yin, J. X., Mark, D., Stedman, J., Appleby, R. S., Booker, J., and Moorcroft, S.: Studies of the coarse particle (2.5$10 \mu \mathrm{m})$ component in UK urban atmospheres, Atmos. Environ., 35, 3667-3679, 2001.

Host, S., Larrieu, S., Pascal, L., Blanchard, M., Declercq, C., Fabre, P., Jusot, J., Chardon, B., Le Tertre, A., Wagner, V., Prouvost, H., and Lefranc, A.: Short-term associations between fine and coarse particles and hospital admissions for cardiorespiratory diseases in six French cities, Occup. Environ. Med., 65, 544-551, 2008.

Houyoux, M., Vukovich, J., Coats, C., Wheeler, N., and Kasibhatla, P.: Emission inventory development and processing for the Seasonal Model for Regional Air Quality (SMRAQ) project, J. Geophys. Res.-Atmos., 105, 9079-9090, 2000.

Jensen, S. S., Larson, T., Deepti, K. C., and Kaufman, J. D.: Modeling traffic air pollution in street canyons in New York City for intra-urban exposure assessment in the US Multi-Ethnic Study of atherosclerosis and air pollution, Atmos. Environ., 43, 45444556, 2009.

Kain, J.: The Kain-Fritsch convective parameterization: an update, J. Appl. Meteorol., 43, 170-181, 2004.

Kelly, J. T., Bhave, P. V., Nolte, C. G., Shankar, U., and Foley, K. M.: Simulating emission and chemical evolution of coarse seasalt particles in the Community Multiscale Air Quality (CMAQ) model, Geosci. Model Dev., 3, 257-273, doi:10.5194/gmd-3257-2010, 2010.

Koehler, K. A., Kreidenweis, S. M., DeMott, P. J., Petters, M. D., Prenni, A. J., and Carrico, C. M.: Hygroscopicity and cloud droplet activation of mineral dust aerosol, Geophys. Res. Lett., 36, L08805, doi:10.1029/2009GL037348, 2009.

Konovalov, I. B., Beekmann, M., Kuznetsova, I. N., Yurova, A., and Zvyagintsev, A. M.: Atmospheric impacts of the 2010 Russian wildfires: integrating modelling and measurements of an extreme air pollution episode in the Moscow region, Atmos. Chem. Phys., 11, 10031-10056, doi:10.5194/acp-11-10031-2011, 2011.

Krueger, B., Grassian, V., Cowin, J., and Laskin, A.: Heterogeneous chemistry of individual mineral dust particles from different dust source regions: the importance of particle mineralogy, Atmos. Environ., 38, 6253-6261, 2004.

Kumar, P., Nenes, A., and Sokolik, I. N.: Importance of adsorption for $\mathrm{CCN}$ activity and hygroscopic properties of mineral dust aerosol, Geophys. Res. Lett., 36, L24804, doi:10.1029/2009GL040827, 2009.

Kumar, P., Sokolik, I. N., and Nenes, A.: Measurements of cloud condensation nuclei activity and droplet activation kinetics of fresh unprocessed regional dust samples and minerals, Atmos. Chem. Phys., 11, 3527-3541, doi:10.5194/acp-11-3527-2011, 2011.

Lagudu, U. R. K., Raja, S., Hopke, P. K., Chalupa, D. C., Utell, M. J., Casuccio, G., Lersch, T. L., and West, R. R.: Heterogeneity of coarse particles in an urban area, Environ. Sci. Technol., 45, 3288-3296, 2011.

Lonati, G., Pirovano, G., Sghirlanzoni, G. A., and Zanoni, A.: Speciated fine particulate matter in northern Italy: A whole year chemical and transport modelling reconstruction, Atmos. Res., 95, 496-514, 2010. 
Mahowald, N.: Aerosol indirect effect on biogeochemical cycles and climate, Science, 334, 794-796, 2011.

Malig, B. J. and Ostro, B. D.: Coarse particles and mortality: evidence from a multi-city study in California, Occup. Environ. Med., 66, 832-839, 2009.

Malm, W. C., Pitchford, M. L., McDade, C., and Ashbaugh, L. L.: Coarse particle speciation at selected locations in the rural continental United States, Atmos. Environ., 41, 2225-2239, 2007.

Mlawer, E., Taubman, S., Brown, P., Iacono, M., and Clough, S.: Radiative transfer for inhomogeneous atmospheres: RRTM, a validated correlated-k model for the longwave, J. Geophys. Res.Atmos., 102, 16663-16682, 1997.

Nenes, A., Pandis, S., and Pilinis, C.: Continued development and testing of a new thermodynamic aerosol module for urban and regional air quality models, Atmos. Environ., 33, 1553-1560, 1999.

Otte, T. L. and Pleim, J. E.: The Meteorology-Chemistry Interface Processor (MCIP) for the CMAQ modeling system: updates through MCIPv3.4.1, Geosci. Model Dev., 3, 243-256, doi:10.5194/gmd-3-243-2010, 2010.

Pakbin, P., Hudda, N., Cheung, K. L., Moore, K. F., and Sioutas, C.: Spatial and temporal variability of coarse $\left(\mathrm{PM}_{10-2.5}\right)$ particulate matter concentrations in the Los Angeles area, Aerosol. Sci. Technol., 44, 514-525, 2010.

Paytan, A., Mackey, K. R. M., Chen, Y., Lima, I. D., Doney, S. C., Mahowald, N., Labiosa, R., and Postf, A. F.: Toxicity of atmospheric aerosols on marine phytoplankton, P. Natl. Acad. Sci. USA, 106, 4601-4605, 2009.

Perez, L., Tobias, A., Querol, X., Kunzli, N., Pey, J., Alastuey, A., Viana, M., Valero, N., Gonzalez-Cabre, M., and Sunyer, J.: Coarse particles from Saharan dust and daily mortality, Epidemiology, 19, 800-807, 2008.

Pierce, T., Geron, C., Bender, L., Dennis, R., Tonnesen, G., and Guenther, A.: Influence of increased isoprene emissions on regional ozone modeling, J. Geophys. Res.-Atmos., 103, 2561125629, 1998.

Pleim, J. E. and Xiu, A. J.: Development of a land surface model. Part II: data assimilation, J. Appl. Meteorol., 42, 1811-1822, 2003.

Reisner, J., Rasmussen, R., and Bruintjes, R.: Explicit forecasting of supercooled liquid water in winter storms using the MM5 mesoscale model, Q. J. R. Meteorol. Soc., 124, 1071-1107, 1998.

Sampson, P. D., Szpiro, A. A., Sheppard, L., Lindstrom, J., and Kaufman, J. D.: Pragmatic estimation of a spatio-temporal air quality model with irregular monitoring data, Atmos. Environ., 45, 6593-6606, 2011.

Sandstrom, T. and Forsberg, B.: Desert dust: an unrecognized source of dangerous air pollution?, Epidemiology, 19, 808-809, 2008.

Sarwar, G., Luecken, D., Yarwood, G., Whitten, G. Z., and Carter, W. P. L.: Impact of an updated carbon bond mechanism on predictions from the CMAQ modeling system: preliminary assessment, J. Appl. Meteorol. Clim., 47, 3-14, 2008.

Sesartic, A. and Dallafior, T. N.: Global fungal spore emissions, review and synthesis of literature data, Biogeosciences, 8, 11811192, doi:10.5194/bg-8-1181-2011, 2011.

Sokhi, R. S., Mao, H., Srimath, S. T. G., Fan, S., Kitwiroon, N., Luhana, L., Kukkonen, J., Haakana, M., Karppinen, A., van den
Hout, K. D., Boulter, P., McCrae, I. S., Larssen, S., Gjerstad, K. I., Jose, R. S., Bartzis, J., Neofytou, P., van den Breerner, P., Neville, S., Kousa, A., Cortes, B. M. and Myrtveit, I.: An integrated multi-model approach for air quality assessment: development and evaluation of the OSCAR Air Quality Assessment System, Environ. Modell. Softw., 23, 268-281, 2008.

Solomon, S., Qin, D., Manning, M., Chen, Z., Marquis, M., Averyt, K. B., Tignor, M., and Miller, H. L. (Eds.): Climate Change 2007: The Physical Science Basis. Contribution of Working Group I to the Fourth Assessment Report of the Intergovernmental Panel on Climate Change (IPCC), Cambridge University Press, Cambridge, United Kingdom, 2007.

Textor, C., Schulz, M., Guibert, S., Kinne, S., Balkanski, Y., Bauer, S., Berntsen, T., Berglen, T., Boucher, O., Chin, M., Dentener, F., Diehl, T., Easter, R., Feichter, H., Fillmore, D., Ghan, S., Ginoux, P., Gong, S., Grini, A., Hendricks, J., Horowitz, L., Huang, P., Isaksen, I., Iversen, I., Kloster, S., Koch, D., Kirkevåg, A., Kristjansson, J. E., Krol, M., Lauer, A., Lamarque, J. F., Liu, X., Montanaro, V., Myhre, G., Penner, J., Pitari, G., Reddy, S., Seland, Ø., Stier, P., Takemura, T., and Tie, X.: Analysis and quantification of the diversities of aerosol life cycles within AeroCom, Atmos. Chem. Phys., 6, 1777-1813, doi:10.5194/acp-6-1777-2006, 2006.

Thornburg, J., Rodes, C. E., Lawless, P. A., and Williams, R.: Spatial and temporal variability of outdoor coarse particulate matter mass concentrations measured with a new coarse particle sampler during the Detroit Exposure and Aerosol Research Study, Atmos. Environ., 43, 4251-4258, 2009.

US EPA: Air Quality Criteria for Particulate Matter, US Environmental Protection Agency, Research Triangle Park, NC, EPA/600/P-99/002aF-bF, 2004.

US EPA: Integrated Science Assessment for Particulate Matter (Final Report), EPA/600/R-08/139F, US Environmental Protection Agency, Washington, DC, 2009.

van Donkelaar, A., Martin, R. V., and Park, R. J.: Estimating ground-level $\mathrm{PM}_{2.5}$ using aerosol optical depth determined from satellite remote sensing, J. Geophys. Res.-Atmos., 111, D21201, doi:10.1029/2005JD006996, 2006.

Wang, L., Hao, J., He, K., Wang, S., Li, J., Zhang, Q., Streets, D. G., Fu, J. S., Jang, C. J., Takekawa, H., and Chatani, S.: A modeling study of coarse particulate matter pollution in Beijing: regional source contributions and control implications for the 2008 summer Olympics, J. Air Waste Manage., 58, 1057-1069, 2008.

Wang, Y., Zhuang, G., Tang, A., Zhang, W., Sun, Y., Wang, Z., and An, Z.: The evolution of chemical components of aerosols at five monitoring sites of China during dust storms, Atmos. Environ., 41, 1091-1106, 2007.

Whitten, G. Z., Heo, G., Kimura, Y., McDonald-Buller, E., Allen, D. T., Carter, W. P. L., and Yarwood, G.: A new condensed toluene mechanism for Carbon Bond CB05-TU, Atmos. Environ., 44, 5346-5355, 2010.

Wilson, W. and Suh, H.: Fine particles and coarse particles: concentration relationships relevant to epidemiologic studies, J. Air Waste Manage., 47, 1238-1249, 1997.

Wurzler, S., Reisin, T., and Levin, Z.: Modification of mineral dust particles by cloud processing and subsequent effects on drop size distributions, J. Geophys. Res.-Atmos., 105, 4501-4512, 2000.

Xiu, A. J. and Pleim, J. E.: Development of a land surface model. Part I: application in a mesoscale meteorological model, J. Appl. 
Meteorol., 40, 192-209, 2001.

Zanobetti, A. and Schwartz, J.: The effect of fine and coarse particulate air pollution on mortality: a national analysis, Environ. Health Perspect., 117, 898-903, 2009.

Zhang, J. F., Hu, W., Wei, F. S., Wu, G. P., Korn, L. R., and Chapman, R. S.: Children's respiratory morbidity prevalence in relation to air pollution in four Chinese cities, Environ. Health Perspect., 110, 961-967, 2002.

Zhang, Y., Liu, P., Queen, A., Misenis, C., Pun, B., Seigneur, C., and $\mathrm{Wu}, \mathrm{S} .:$ A comprehensive performance evaluation of MM5CMAQ for the summer 1999 southern oxidants study episode Part II: gas and aerosol predictions, Atmos. Environ., 40, 48394855, 2006.
Zhu, D., Kuhns, H. D., Brown, S., Gillies, J. A., Etyemezian, V., and Gertler, A. W.: Fugitive dust emissions from paved road travel in the Lake Tahoe basin, J. Air Waste Manage., 59, 1219-1229, 2009. 